Article

\title{
The Distribution, Character, and Rhenium Content of Molybdenite in the Aitik Cu-Au-Ag-(Mo) Deposit and Its Southern Extension in the Northern Norrbotten Ore District, Northern Sweden
}

\section{Christina Wanhainen ${ }^{1, *}$, Wondowossen Nigatu ${ }^{2}$, David Selby ${ }^{3}$, Claire L. McLeod ${ }^{4}$, Roger Nordin ${ }^{5}$ and Nils-Johan Bolin ${ }^{6}$}

1 Division of Geosciences and Environmental Engineering, Luleå University of Technology, SE 97187 Luleå, Sweden

2 Gunnarn Exploration AB, Blåvagen 207 Box 149, SE 92323 Storuman, Sweden; E-Mail: wondossenbekele@yahoo.com

3 Department of Earth Sciences, University of Durham, Durham DH1 3LE, UK; E-Mail: david.selby@durham.ac.uk

4 Department of Earth and Atmospheric Sciences, University of Houston, Houston, TX 77204-5007, USA; E-Mail: clmcleod@central.uh.edu

5 Exploration Department, Boliden Mineral AB, SE 93681 Boliden, Sweden; E-Mail: roger.nordin@boliden.com

6 Division of Process Technology, Boliden Mineral AB, SE 93681 Boliden, Sweden; E-Mail: nils-johan.bolin@boliden.com

* Author to whom correspondence should be addressed; E-Mail: chwa@1tu.se; Tel.: +46-920-492-401; Fax: +46-920-491-399.

External Editor: Thomas N. Kerestedjian

Received: 23 September 2014; in revised form: 21 November 2014 / Accepted: 24 November 2014 / Published: 1 December 2014

\begin{abstract}
Molybdenite in the Aitik deposit and its southern extension was studied through mineralogical/chemical analysis and laboratory flotation tests. It is demonstrated that molybdenite varies considerably in grain size, ranging from coarse $(>20 \mu \mathrm{m})$ to very fine $(<2 \mu \mathrm{m})$ and occurs predominantly as single grains in the groundmass of the rocks, as grain aggregates, and intergrown with chalcopyrite and pyrite. The dominating molybdenite-bearing rocks are the mica schists, the quartz-monzodiorite, and the Salmijärvi biotite-amphibole gneiss, the latter containing mostly medium-coarsegrained
\end{abstract}


molybdenite. Later geological features, such as garnet-magnetite-anhydrite-K feldspar alteration and pegmatite dikes appear to be responsible for a significant part of the distribution pattern of molybdenite. Molybdenite grains contain up to $1587 \mathrm{ppm}$ Re, with an average of $211 \pm 10 \mathrm{ppm}$ in Aitik molybdenite and $452 \pm 33 \mathrm{ppm}$ in Salmijärvi molybdenite. The higher Re concentrations are found in molybdenite associated with sericite- and quartz-amphibole-magnetite altered rocks, whereas low Re values occur in rocks in which potassic alteration is prominent. Molybdenite recovery is influenced by the mineralogy of the host rock and the alteration grade; hence both of these factors will have an impact on potential recoveries. The recovery of molybdenite was lower from flotation feeds with significant amounts of Mg-bearing clay-micas.

Keywords: Aitik deposit; northern Sweden; molybdenite; rhenium; QEMSCAN; dilution ICP-MS; mineral processing; ore characterization

\section{Introduction}

The Aitik porphyry $\mathrm{Cu}-\mathrm{Au}-\mathrm{Ag}-(\mathrm{Mo})$ deposit is located $60 \mathrm{~km}$ north of the Arctic Circle at latitude $67^{\circ} 04^{\prime} \mathrm{N}$ and longitude $20^{\circ} 57^{\prime} \mathrm{E}$ in the Gällivare area in northern Sweden (Figure 1). The mineralization extends for $\sim 5 \mathrm{~km}$ with a maximum width of $400 \mathrm{~m}$, and is known to extend to a maximum depth of $800 \mathrm{~m}$ in the deepest investigated parts (Figure 2). The Aitik mine is by size the largest open-pit metal mine in Europe and the main pit measures over $3 \mathrm{~km}$ in length, $1.1 \mathrm{~km}$ in width and $435 \mathrm{~m}$ in depth (Figure 2). Production in the Salmijärvi open-pit, which is situated in the southern strike prolongation of the Aitik main pit and planned to be $800 \mathrm{~m}$ long, $400 \mathrm{~m}$ wide and $275 \mathrm{~m}$ deep, started at the end of 2010 (Figure 2). The Aitik deposit was discovered in 1932 and has been in production since 1968 when it started as a $2 \mathrm{Mt} /$ year open-pit operation. Since then over $632 \mathrm{Mt}$ of ore has been mined averaging $0.35 \% \mathrm{Cu}, 0.18 \mathrm{ppm} \mathrm{Au}$ and $3.4 \mathrm{ppm} \mathrm{Ag}$. Production in 2013 was $37 \mathrm{Mt}$ of ore with an output of 70,927 tonnes of $\mathrm{Cu}, 1765 \mathrm{~kg}$ of $\mathrm{Au}$, and 53,612 $\mathrm{kg}$ of $\mathrm{Ag}$. Ore reserves at the announcement of the Aitik $45 \mathrm{Mt}$ expansion project in May 2014, were $1085 \mathrm{Mt}$ grading $0.22 \% \mathrm{Cu}, 0.14 \mathrm{ppm} \mathrm{Au}$, $1.5 \mathrm{ppm} \mathrm{Ag}$ and $26 \mathrm{ppm} \mathrm{Mo}$, with remaining measured and indicated mineral resources totaling $1716 \mathrm{Mt}$.

A major mine expansion program for Aitik has recently been finished to reach $36 \mathrm{Mt}$ of annual ore production, and a decision to go for $45 \mathrm{Mt}$ capacity was taken in early summer 2014. Future plans for the Aitik mine also include a study which will assess the possibility of commencing molybdenum extraction. To date, no studies have been performed on the occurrence of molybdenite within the ore body, a detailed characterization of this mineral is essential in order to maximize future recovery of molybdenum. With current metal prices it is important to characterize the ore body of its minor components and to map and characterize metallurgical parameters that could affect the ore value, regardless if the minor component constitutes a penalty metal or a bonus metal. Since rhenium occurs naturally in molybdenite [1], extraction of molybdenite through flotation would yield a rhenium-bearing molybdenite concentrate that has a potentially higher market value. 
Figure 1. Geology of the Gällivare area (modified from [2]). Inset shows the location of the Gällivare area (rectangle) and the Aitik deposit (star) within the Fennoscandian Shield.
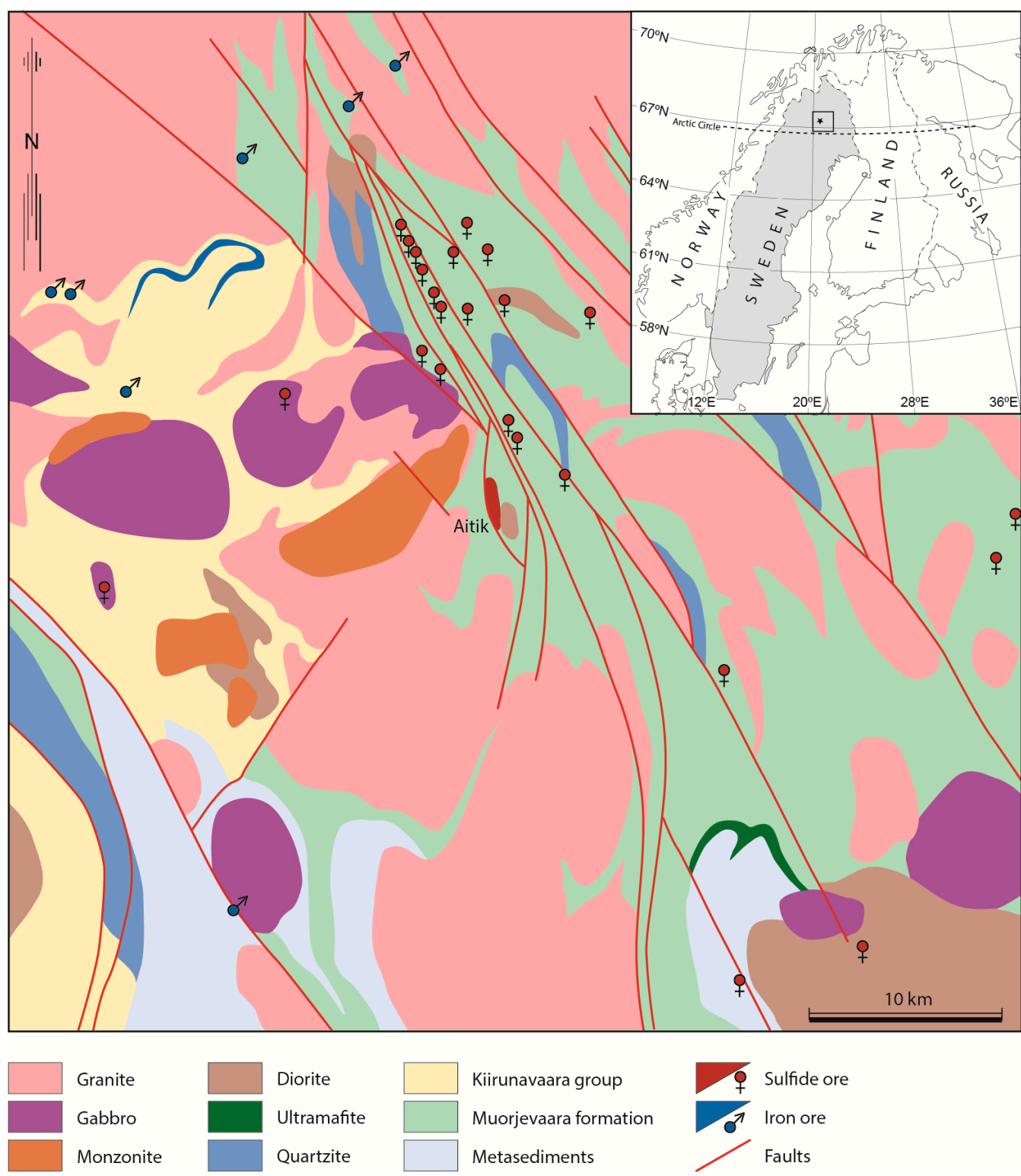

The Aitik and Salmijärvi ore bodies that are presented by this study are Palaeoproterozoic deposits which have been modified by multistage metamorphic-tectonic and magmatic-hydrothermal events. Redistribution of metals and possible addition of ore minerals from a later mineralizing event has led to a wide variety of mineralization styles and a complex mineralization pattern [3]. This pattern has been studied in detail regarding copper, and to some extent gold [4,5].

In this paper, we describe the character of molybdenite in the Aitik deposit, and demonstrate the application of qualitative and quantitative mineralogical data derived from optical microscope, QEMSCAN (Quantitative evaluation of minerals by scanning electron microscopy) and ICP-MS (Inductively coupled plasma mass spectrometry) to genetic and mineral processing issues. The results will form an integral part of the input required for a future blockmodel where the geological, mineralogical and metallurgical character of the ore is combined, and the true value of this deposit assessed accurately. 
Figure 2. Geology and open pit contours of the Aitik and Salmijärvi deposits and their close surroundings. Local coordinates in meter; (a) Horizontal section at 100-200 m depth; (b) Schematic E-W vertical section of the Aitik deposit; (c) Schematic E-W vertical section of the Salmijärvi deposit. Modified from [6].

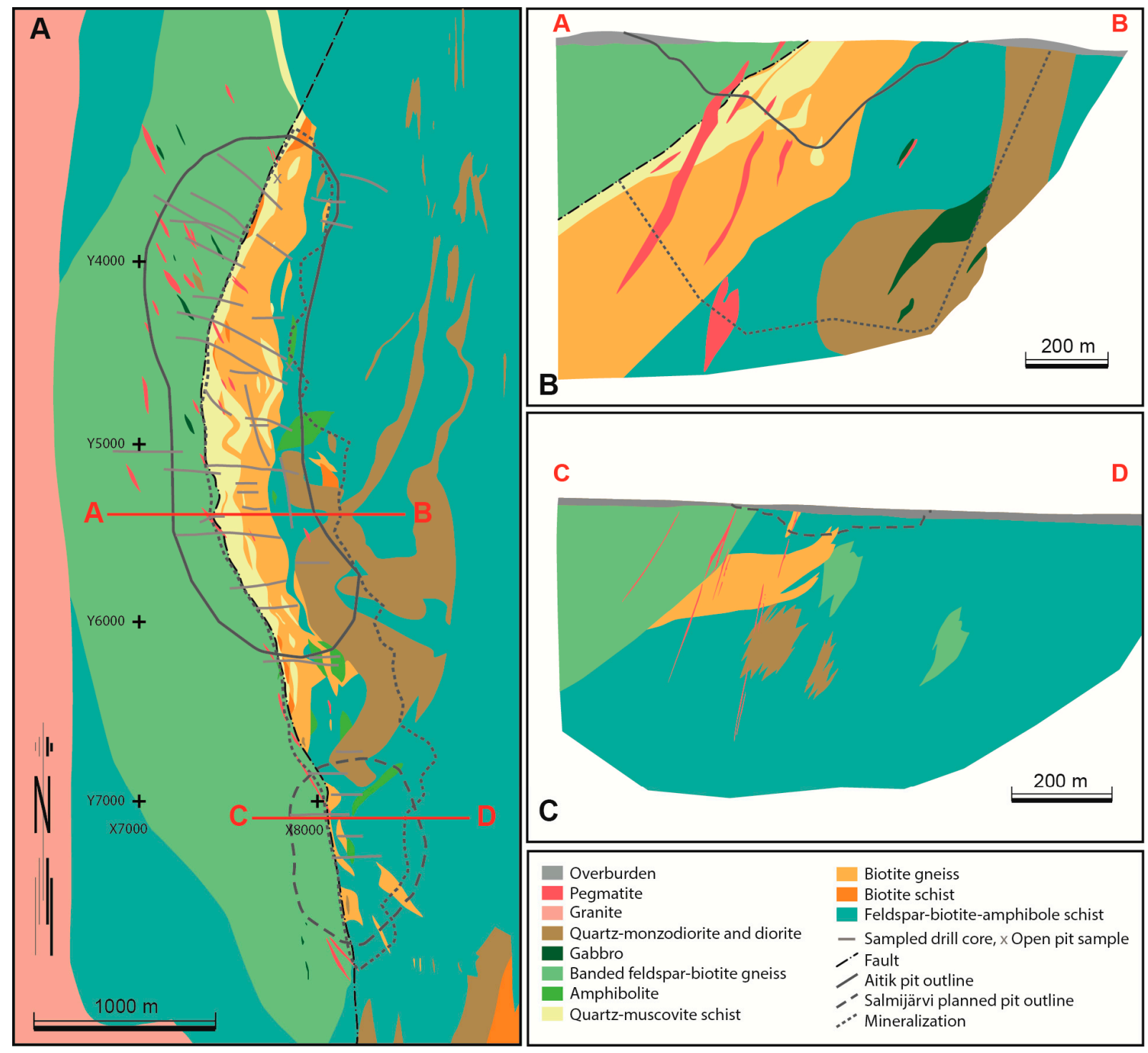

\section{Geology}

The Aitik porphyry $\mathrm{Cu}-\mathrm{Au}-\mathrm{Ag}$-(Mo) deposit and its host rocks, situated $200 \mathrm{~km}$ north of the Archaean-Proterozoic palaeoboundary in the Fennoscandian shield, are understood to have formed in a volcanic arc environment related to subduction of oceanic crust beneath the Archaean craton at ca. $1.9 \mathrm{Ga}$ [7]. A quartz monzodioritic intrusion related to the formation of porphyry copper mineralization is situated in the footwall of the deposit (Figure 2). This source intrusion and related volcaniclastic rocks are mafic-intermediate in composition and belong to the regionally widespread Haparanda suite of intrusions and the Porphyrite group of volcanic rocks, respectively [8]. The deposit is overprinted by a hydrothermal event of Iron Oxide $\mathrm{Cu}-\mathrm{Au}$ (IOCG) type at ca. $1.8 \mathrm{Ga}$ [3] and strongly deformed and metamorphosed at amphibolite facies, resulting in at least $160 \mathrm{Ma}$ of post-ore modification [9]. 


\section{Deposit Geology}

The Aitik quartz monzodiorite intrusion is comprised of younger, comagmatic, intrusions of micro-quartz monzodiorite and diorite, and is suggested to represent a cupola protruding from a pluton at depth [7]. It is typically grey and plagioclase-porphyritic with a medium grained groundmass of plagioclase, biotite, K-feldspar and quartz, and trace amounts of titanite, apatite and zircon [7]. It should be noted that the quartz monzodiorite intrusion is metamorphosed, and should accordingly be called gneiss. However, in order to stress the intrusion-related origin of the deposit this has not been applied below.

The surrounding volcaniclastic rocks constitute feldspar-biotite-amphibole gneisses in the footwall and hanging wall, and quartz-muscovite schist and biotite schist/gneiss in the ore zone (Figure 2). The feldspar-biotite-amphibole gneiss in the footwall to the ore is composed of large (6000 to 20,000 $\mu \mathrm{m}$ ) amphibole phenocrysts in a groundmass of feldspar, biotite and amphibole, with accessory apatite, titanite, zircon and opaque phases. The hangingwall feldspar-biotite-amphibole gneiss is grey-greenish to grey-brownish in color and fine-grained $(\sim 200 \mu \mathrm{m})$. Abundant accessory magnetite and titanite occur in a groundmass of plagioclase, biotite, amphibole and quartz. The hangingwall gneiss is separated from the ore zone by a thrust (Figure 2).

The dominant rock type in the ore zone is the light grey, garnet-bearing biotite gneiss with approximately $1 \%$ to $2 \%$ garnet porphyroblasts. The microcrystalline groundmass contains K-feldspar, plagioclase, biotite, amphibole, quartz, and opaque minerals, and accessory minerals that include tourmaline, apatite, fluorite and titanite. The quartz-muscovite schist is commonly sericite-altered and mainly comprises muscovite, K-feldspar, quartz, sericite and tourmaline, with accessory apatite and opaque phases. Pyrite is common. Lenses of micro-quartz monzodiorite can be distinguished within less foliated sections of the ore zone schist and gneiss.

Several generations of pegmatitic dykes, barite veins, and quartz-sulfide veins occur in the Aitik mining area. The pegmatites strike either north-south or east-west and range in thickness from 0.5 to $20 \mathrm{~m}$. Pegmatites within the ore zone and footwall frequently contain pyrite and chalcopyrite, and occasionally molybdenite, in addition to plagioclase, quartz, microcline, muscovite, biotite and tourmaline. Pegmatite dykes in the hangingwall are predominantly barren. Pegmatites striking north-south, i.e., along the main foliation, in places display deformation features such as folding, while those crosscutting the foliation in an east-west direction, are always underformed. Ages of pegmatite dykes range between 1850 to $1730 \mathrm{Ma}$ [9].

The main copper-bearing mineral at Aitik is chalcopyrite, which is often disseminated. Bornite and chalcocite are present in trace amounts. Other ore minerals include pyrite, magnetite, pyrrhotite, ilmenite, molybdenite, gold, and silver. Molybdenite is sporadically observed in the ore zone and footwall of the deposit, usually in association with chalcopyrite and/or pyrite, in quartz veins of varying composition, and as coarse aggregates within pegmatite dykes. Gold occurs as native metal in amalgam and in electrum [5], in close association with groundmass minerals such as $\mathrm{K}$ feldspar, biotite, plagioclase and quartz, but also with chalcopyrite and pyrite [10]. To date, the distribution of silver and its mode of occurrence has not been studied in detail, but the majority of the silver is likely to be hosted within the chalcopyrite [11]. 
Salmijärvi constitutes the southern extension of the Aitik ore body and comprises of strongly altered and metamorphosed biotite gneiss, amphibole-biotite gneiss and amphibole gneiss within the ore zone (Figure 2). These gneisses seem to be of slightly higher metamorphic grade and/or more strongly hydrothermally altered than the rocks in the Aitik main ore zone, although show similar folding styles and well developed foliations. As with the Aitik ore body, the Salmijärvi ore is crosscut by weakly mineralized pegmatite dykes and occasional quartz dykes. Quartz monzodioritic bodies occur on the footwall side of the ore (Figure 2). The hanging wall rocks consist of the same hornblende-banded garnet-porphyroblastic amphibole gneiss. In the ore zone, westward, the biotite gneiss becomes more schistose [12]. Commonly there are $\mathrm{mm}$ - to $\mathrm{cm}$-sized green hornblende veinlets, surrounded by albite haloes within the Salmijärvi area. These veins often have a central line of chalcopyrite and are rimmed by quartz and feldspar, i.e., very similar to the footwall mineralization in the Aitik main pit. The hornblende veins are often short (dm-size), sometimes with a vuggy appearance [13]. The contact between the ore zone and the hanging wall rocks is sharp and dipping $60^{\circ}$ to the west, whereas the western ore body contact is grade controlled and thus gradational. The hanging wall contact is curved and the ore body pinches out towards the south. The contact can be seen cut by thin pegmatite dykes. The muscovite schist with common pyrite in Aitik is absent in Salmijärvi. The majority of the molybdenite is associated with quartz veins/blebs of slightly varying composition. Molybdenite occurs as small grains and clusters within $\mathrm{mm}$ to $\mathrm{cm}$ sized quartz veinlets, within $\mathrm{mm}$ to $\mathrm{cm}$ away from the quartz veins, and within dm sized quartz blebs. The quartz veins form a weak stockwork which often contains pyrite and chalcopyrite as well. The quartz stockwork forms $1 \%-5 \%$ of the host rock. Molybdenite also occurs as trace dissemination in the host rock.

\section{Sampling and Methods}

Sixty-four samples were taken from 33 drill cores from the Salmijärvi and Aitik deposits, and from the Aitik open pit. Samples were taken from different lithologies and alteration- and mineralization assemblages. Samples contained molybdenite that was both visible and not visible by the naked eye. Polished thin sections were prepared by Vancouver Petrographics Ltd, Langley, Canada, and were examined in detail to document wall rock, alteration- and mineralization phases. In order to document and characterize the different molybdenite mineralization phases, a detailed optical examination of polished thin sections in reflected and transmitted light using a standard petrographic microscope (Nikon ECLIPSE E600 POL, Nikon Instruments, Amsterdam, The Netherlands) was conducted before and after QEMSCAN, ICP-MS, and flotation analyses.

\subsection{QEMSCAN Analysis}

In order to assess all size fractions, and thereby obtain a reliable compilation of the overall molybdenite content at Aitik and Salmijärvi, and to be able to search a large number of samples, QEMSCAN analyses were performed. Identification of molybdenite in 30 polished thin sections by $\mathrm{X}$-ray and image analysis was performed at the QEMSCAN laboratory of Intellection UK in North Wales. Polished thin sections were measured using a fieldscan operating mode with a beam-stepping interval of $25 \mu \mathrm{m}$. Fieldscan analyses are based on between 578,797 and 767,112 individual EDS (Energy-dispersive X-ray spectroscopy) analyses per thin section. Samples were then 
analyzed using the trace mineral search (TMS) mode. The backscatter electron threshold was set at 115 so that any grains "brighter" than chalcopyrite (e.g., molybdenite) were identified, and the selected grains and surrounding area were mapped using a beam-stepping interval of $1 \mu \mathrm{m}$. Thirteen complementary samples were analyzed at the QEMSCAN laboratory of LKAB MetLab in Luleå, Sweden. Polished thin sections were measured using the trace mineral search (TMS) mode with a beam-stepping interval of $5 \mu \mathrm{m}$. The backscatter electron threshold was set at 121 . Fieldscan analyses were performed on specific areas that were re-mapped using a beam stepping interval of $1 \mu \mathrm{m}$. Some of the molybdenite grains (ca. 100-150) detected by QEMSCAN were re-located in the optical microscope in order to study mineral associations and related textures in more detail.

\subsection{Molybdenite Re Abundance Determination}

Seventeen drill core samples with visible molybdenite were selected for dilution ICP-MS analysis in order to determine the rhenium content of individual molybdenite grains (Table 1). Localized variation in Re abundance in the molybdenite grain [14-16] was avoided by isolating the entire area of molybdenite. Selection of molybdenite grains was done in polished thin sections together with their copy of rock chips using a high magnification Nikon Microscope at the Division of Geosciences at Luleå University of Technology, Sweden. Grains were chosen so that a variety of sizes, mineral associations and host rocks would be represented. Sampled molybdenite were extracted from the rock chips using a New Wave ${ }^{\mathrm{TM}}$ (Fremont, CA, USA) micro drill at Arthur Holmes Isotope Geology Laboratory (AHIGL) which is part of the Durham Geochemistry Centre at Durham University, UK.

The Micro drill instrument contains three basic parts; a Binocular Microscope, a high speed drill with adjustable tungsten carbide and an XYZ stage. All the components are integrated with a workstation allowing for high precision $( \pm 1 \mu \mathrm{m})$ movement of the drill. See [17] for further details of the microdrill setup.

Rock chips containing grains of molybdenite were first attached and mounted with double sided tape on the sample plate stage. Molybdenite was sampled using $c a .30 \mu \mathrm{m}$ diameter drill bit and a $40 \mu \mathrm{m}$ drill depth. Depending on grain size, several samples were taken from each grain in order to maximize the recovery of molybdenite. After each grain was sampled, the rock chip was cleaned in an ultrasonic bath in ethanol [17] and the drill bit replaced in order to avoid contamination.

Recovery of the molybdenite separate was achieved using a flotation technique with high purity water (MilliQ, Darmstadt, Germany) by a $0.5-10 \mu \mathrm{L}$ micropipette which sucked up the floated molybdenite grains or dry separation technique (to minimize impurities such as quartz, biotite, amphibole, chalcopyrite, pyrite and magnetite) using a high magnification microscope. A total of 27 molybdenite grains were individually weighed on a gold boat using a Mettler Todeo UMT2 balance (Mettler-Toledo Ltd., Leicester, UK). The weight of the samples extracted for analysis ranged from 0.001 to $0.088 \mathrm{mg}$ (Table 1). The molybdenite was washed from the gold boat in a $3.5 \mathrm{~mL}$ savillex vial with $0.25 \mathrm{~mL}$ of concentrated $\mathrm{HCl}$ at $80{ }^{\circ} \mathrm{C}$ overnight $(>12 \mathrm{~h}$ ). Following this stage the gold boat was removed from the vial. The molybdenite in $0.25 \mathrm{~mL}$ of concentrated $\mathrm{HCl}$ was then digested in a known amount of $185 \mathrm{Re}$ tracer solution together with $0.5 \mathrm{~mL}$ concentrated $\mathrm{HNO}_{3}$ at $130{ }^{\circ} \mathrm{C}$ for $\sim 24 \mathrm{~h}$. Following digestion the sample was evaporated to dryness at $80{ }^{\circ} \mathrm{C}$ and then prepared for ICP-MS analysis by the addition of $1 \mathrm{~mL} 0.8 \mathrm{~N} \mathrm{HNO}_{3}$. 


\subsection{Laboratory Flotation Tests}

To investigate the flotation response of different ore types (with variable molybdenum content) in the Aitik deposit, laboratory flotation tests were performed on 14 drill core samples after 7 and $11 \mathrm{~min}$ of grinding. Samples consist of approximately $10-15 \mathrm{~kg}$ of drill core each. Metallurgical testing was performed at the mineral laboratory of the Processing department (TMP) at Boliden Mineral.

Samples were obtained from representative, homogenous sections in drill cores. Drill cores were chosen so that sampling would cover the major lithologies and alteration- and mineralization types present in Aitik (except pegmatite dykes), and all samples were studied and documented in detail in hand specimen and polished thin sections before grinding. Molybdenite was not visible by the naked eye in any of the samples. Each sample was passed through a $3 \mathrm{~mm}$ screen and the oversize was crushed to below $3 \mathrm{~mm}$. The sample was then split into $1 \mathrm{~kg}$ posts and stored for further treatment.

At each test, $1 \mathrm{~kg}$ of material was placed in a laboratory rod mill with an $8.0 \mathrm{~kg}$ rod charge and $550 \mathrm{~mL}$ of water. A $\Phi 195 \mathrm{~mm} \times 245 \mathrm{~mm}$ stainless steel mill was used, rotating with $48 \mathrm{rpm}$. The diameters of the stainless rods are varying continuously from a maximum of $25 \mathrm{~mm}$, down to about $5 \mathrm{~mm} .7$ and $11 \mathrm{~min}$ grinding time were chosen, generating particle size distributions (PSD: s) similar to a distribution from the Aitik plant. The laboratory rod mill produces less coarse particles than the autogenous grinding circuits in the plant but this does not normally affect the results.

After grinding, the pulp was transferred to a $2.5 \mathrm{~L}$ flotation cell. Flotation trials were conducted in a Wemco laboratory flotation unit, with a mixing speed of $1200 \mathrm{rpm}$. Tap water was added and the $\mathrm{pH}$ noted varied between 8.0 and 8.7 in the different tests. After conditioning for 5 min at $\mathrm{pH} 10.5$ with slaked lime, $\mathrm{Cu}$ rougher flotation tests were run in 4 sequential steps with 1, 2, 3, and 3 min flotation times. Before each flotation step, a 1-min conditioning time was allowed for adding $5 \mathrm{~g} /$ tonnes of collector, frother was added if needed. Potassium xanthate (KAX) is used as collector in Aitik. The frother is a glycol, ether/glycol mixture (Nasfroth 350). All flotation products were filtered and dried and the dry weight was noted.

Each test consisted of three parallel flotation tests for which a total of $3 \mathrm{~kg}$ material was needed. Through this methodology enough amounts of products were produced for the assaying. Flotation products were analyzed with X-ray for a multitude of elements including $\mathrm{Cu}, \mathrm{Mo}$ and $\mathrm{S}$. This work was done at the Aitik process laboratory and required $12 \mathrm{~g}$ of each product.

\section{Results}

By performing petrographic, QEMSCAN, ICP-MS, and flotation laboratory test studies on molybdenite, the diversity of its character, occurrence, and rhenium content, and its response to the standard copper flotation procedure used for the Aitik ore has been thoroughly characterized. In the studied area, molybdenite grain size varies from coarse $(>20 \mu \mathrm{m})$ to very fine $(<2 \mu \mathrm{m})$ and occurs mainly as single grains in the groundmass of the rocks, as grain aggregates, and as intergrowths with chalcopyrite and pyrite. The molybdenite-bearing rocks are the biotite- and muscovite schists in the Aitik ore zone, the quartz monzodiorite in the Aitik footwall, and the Salmijärvi biotite-amphibole gneiss, the latter containing mostly medium-coarse grained molybdenite. In summary the rhenium 
abundance of molybdenite varies between 20-1587 ppm, with the higher contents obtained from Salmijärvi molybdenite samples.

\subsection{QEMSCAN Analysis of the Distribution and Character of Molybdenite}

Of the 36 samples from Aitik analyzed by QEMSCAN, 26 contain molybdenite and a total of 8336 molybdenite grains were found. The majority of molybdenite grains occur as 10-100 $\mu \mathrm{m}$ rectangular or subrectangular flakes lying individually or intergrown with each other (Figure 3a). Molybdenite grains in Aitik are dominantly associated with anhydrite, chalcopyrite, pyrite, biotite and $\mathrm{K}$ feldspar in mica schists and in quartz monzodiorite (Figures $3 \mathrm{a}-\mathrm{c}$ and 4), and occasionally in pegmatite. The richest sample, containing 3047 molybdenite grains, is garnet-magnetite-quartz-anhydrite-altered biotite schist dominated by biotite, anhydrite, tourmaline and feldspar with minor sulfides. A similar sample, containing 2311 molybdenite grains, is an amphibole-quartz-sulfide-altered quartz monzodiorite, with amphibole, zeolite, quartz and anhydrite. The overall grain size distribution of molybdenite grains in Aitik is shown in Figure 5.

Figure 3. Photomicrographs of characteristic molybdenite in Aitik and Salmijärvi. Reflected light; (a) Scattered molybdenite grains in quartz monzodiorite in Aitik (sample Agm751-246.7). Majority of grains are 10-100 $\mu \mathrm{m}$; (b) Molybdenite aggregate in anhydrite vein in homogeneous quartz monzodiorite in Aitik (sample Agm751-246.7); (c) Coarse-grained molybdenite intergrown with chalcopyrite in brittle mica schist in Aitik (sample Am652-518.4); (d) Coarse-grained molybdenite associated with magnetite and chalcopyrite in biotite-amphibole gneiss in Salmijärvi (sample Sm1022-138.3).
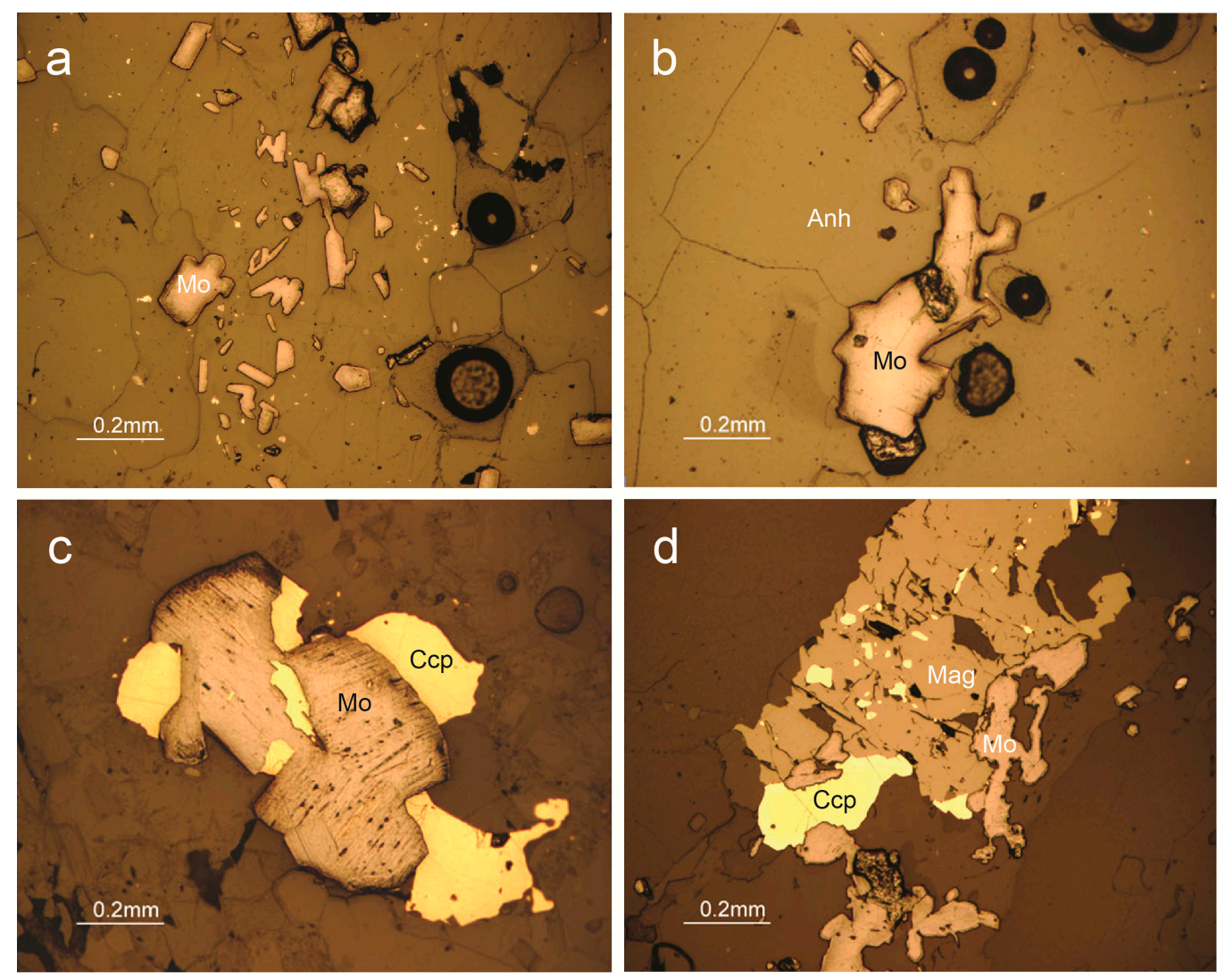
Figure 4. Average number of molybdenite grains displayed for each rock type and for three different size fractions. Graphs are based on number of grains detected by QEMSCAN in 31 polished thin section samples of $26 \mathrm{~mm} \times 46 \mathrm{~mm}$ size.
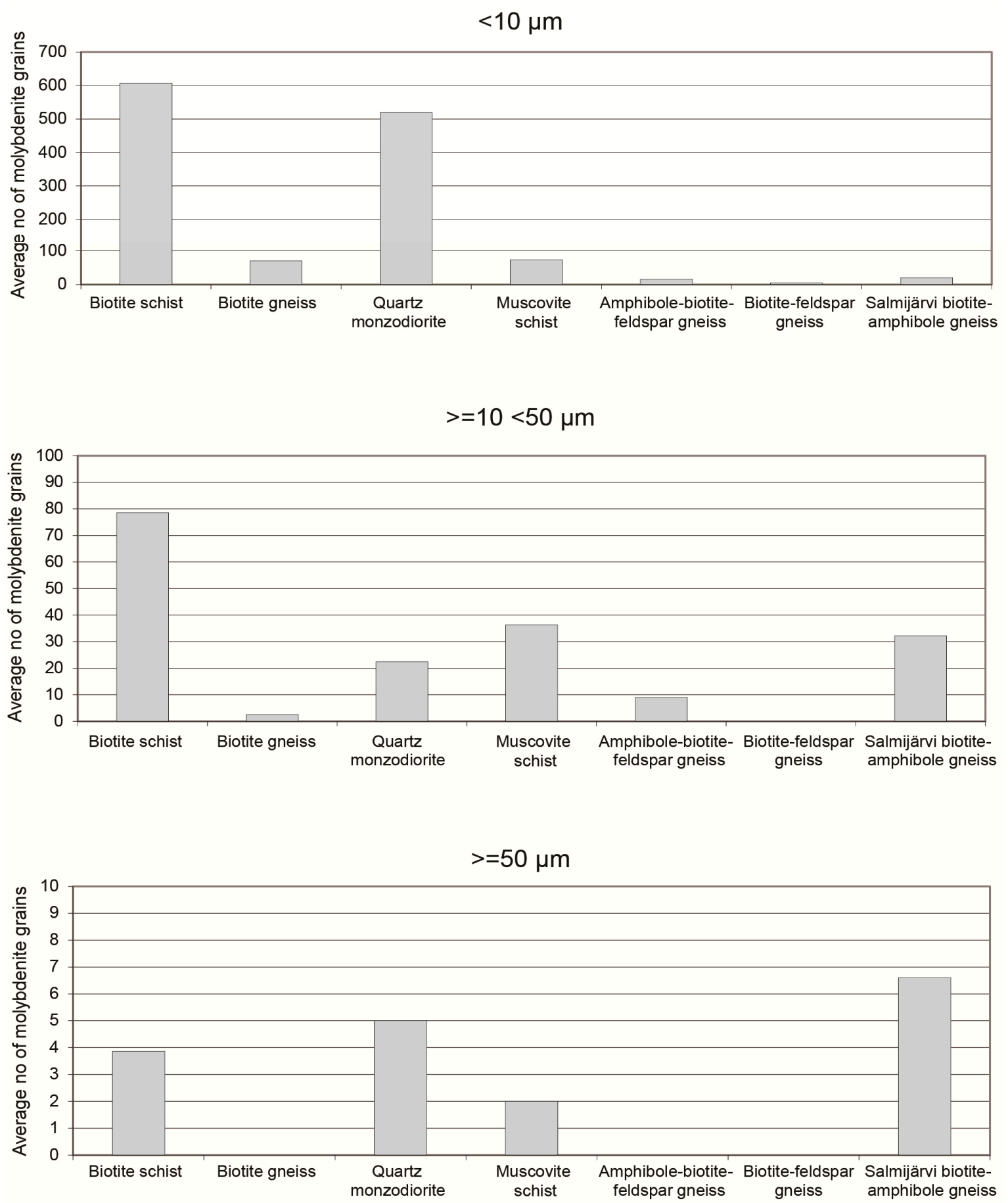

Of the seven samples from Salmijärvi analyzed by QEMSCAN, five contain molybdenite and a total of 549 molybdenite grains were found. Molybdenite grains occur mainly as $7-185 \mu \mathrm{m}$ rectangular and rounded flakes dominantly associated with $\mathrm{K}$ feldspar, quartz, plagioclase, and sulfides in biotite gneiss and bioite-amphibole gneiss, and occasionally in pegmatite. The richest sample, containing 538 molybdenite grains, is a $\mathrm{K}$ feldspar-altered biotite gneiss with sporadic sulfide-magnetite-apatite-alteration patches. A grain size distribution built upon the type of alteration present is clearly outlined in this 
sample, with grains $\leq 10 \mu \mathrm{m}$ mainly associated with $\mathrm{K}$ feldspar, quartz, and biotite, and grains 10-185 $\mu \mathrm{m}$ associated with chalcopyrite, pyrite, magnetite, $\mathrm{K}$ feldspar, quartz, biotite, and apatite (Figure 3d). The overall grain size distribution of molybdenite grains in Salmijärvi is shown in Figure 5.

Figure 5. Size distribution diagram for molybdenite grains in the Aitik (27 samples) and Salmijärvi (5 samples) deposits. Circles symbolize one grain.

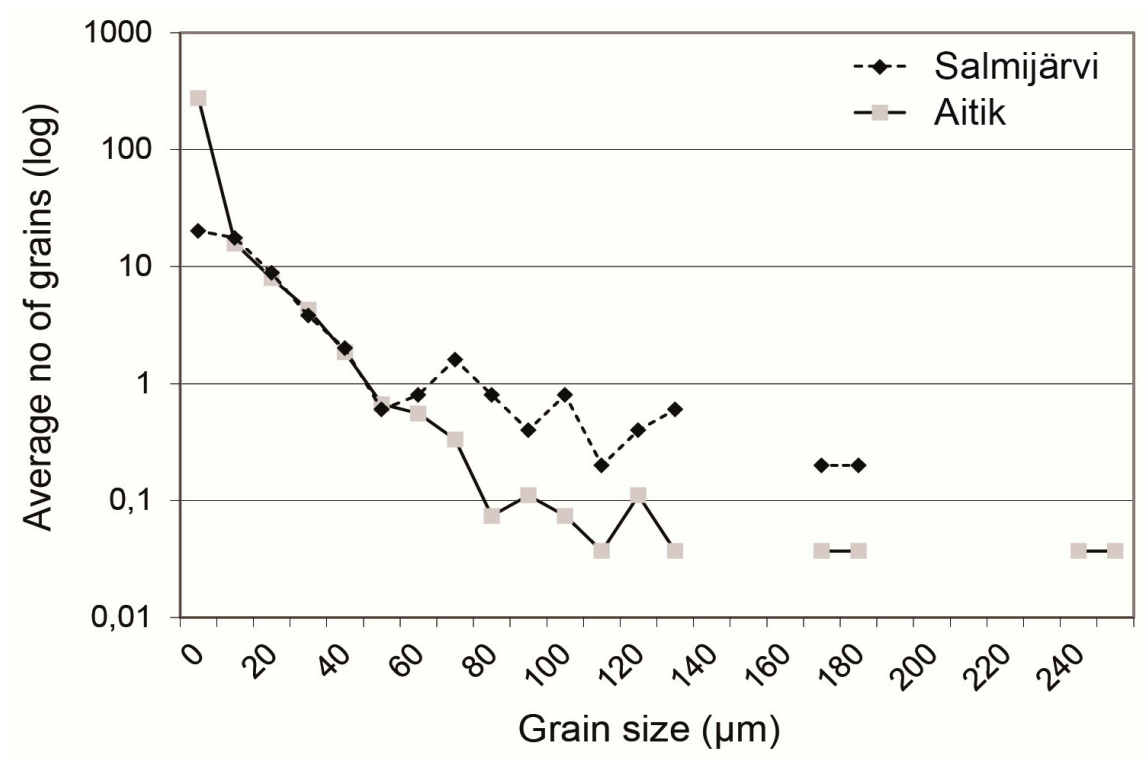

\subsection{Rhenium Abundance of Molybdenite}

The rhenium content of molybdenite grains from the two studied deposits show significant variation (20 to $1587 \mathrm{ppm}$ ) as summarized in Table 1. In Figure 6, the concentration of rhenium measured in each grain is presented in relationship to the setting of the grain (associated host rock, and alterationand mineralization type).

In Aitik, an average Re content of $211 \pm 10 \mathrm{ppm}(4.7 \% 1 \sigma, n=15)$ is obtained. Samples of garnet-bearing biotite gneiss and pegmatite generally contain molybdenite with low concentrations of Re (on average 116 and 117 ppm, respectively) while samples of quartz monzodiorite and quartz-muscovite-(sericite) schist generally contain higher concentrations of Re in molybdenite (on average 334 and $310 \mathrm{ppm}$, respectively, Figure 6a). Molybdenite from two generations of pegmatite dykes were analyzed and revealed a low-Re concentration for molybdenite within the old ( $c a .1 .85 \mathrm{Ga})$ and deformed pegmatite dyke, and a medium-Re concentration for molybdenite within the young (ca. $1.73 \mathrm{Ga}$ ) and cross-cutting pegmatite dyke (Table 1). In Salmijärvi, an average Re content of $452 \pm 33$ ppm $(7.3 \% 1 \sigma, n=10)$ is obtained. Samples of amphibole-(biotite) gneiss generally contain low-Re molybdenite (on average $155 \mathrm{ppm}$ ) while samples of biotite-(amphibole) gneiss contain high-Re molybdenite (on average 650 ppm) (Figure 6a). 
Table 1. Rhenium concentration of molybdenite grains. Mineral abbreviations listed in [18].

\begin{tabular}{|c|c|c|c|c|c|}
\hline Sample code (Mo) & Host rock & Sample description & $\begin{array}{l}\text { Sample code } \\
(\mathbf{R e})\end{array}$ & $\begin{array}{c}\text { MoS }_{2} \text { weight } \\
(\mathbf{m g})\end{array}$ & $\begin{array}{c}\text { Calc Re abundance } \\
\text { (ppm) }\end{array}$ \\
\hline Agm806-61.6 & Qtz-ms schist & $\begin{array}{l}\text { Qtz-ep-alteration with rich dissem of ccp, py, mag, and with scattered Mo } \\
\text { grains assoc with matrix-qtz }\end{array}$ & 1 & 0.012 & $20 \pm 1$ \\
\hline Agm1041-111.5 & Qtz-ms schist & $4 \mathrm{~m}$ wide qtz-(cal) vein. Mo, ccp, py scattered in qtz & 2 & 0.037 & $289 \pm 5$ \\
\hline \multirow{2}{*}{ Am969-493.0 } & Bt gneiss & $\begin{array}{l}1 \mathrm{~m} \text { wide vein of qtz, fsp, bt, ms, chl, tur, and few ccp grains. Mo between fsp } \\
\text { and bt-ms-chl clot }\end{array}$ & 3 & 0.041 & $120 \pm 2$ \\
\hline & Bt gneiss & $\begin{array}{l}1 \mathrm{~m} \text { wide vein of qtz, fsp, bt, ms, chl, tur, and few ccp grains. Mo within } \\
\text { bt-ms-chl clot }\end{array}$ & 4 & 0.018 & $67 \pm 2$ \\
\hline Sgm1021-119.5 & Am-(bt) gneiss & $\begin{array}{l}\text { Sporadic am-fsp-qtz-cal-chl-mag-py-(ccp)-clots with Mo. Mo assoc with } \\
\text { am-fsp }\end{array}$ & 5 & 0.054 & $148 \pm 2$ \\
\hline P-EW & Pegmatite in bt-fsp-am gneiss & $\begin{array}{l}6 \mathrm{~cm} \text { wide, undeformed, E-W trending (cutting main foliation). Composed of } \\
\text { fsp-qtz-(bt) with accessory py, ccp, mag, Mo. Mo assoc with fsp-qtz }\end{array}$ & 6 & 0.026 & $172 \pm 4$ \\
\hline Am1042-542.3 & Qtz monzo-diorite & $\begin{array}{l}5 \mathrm{~m} \text { section of strong ser-ep-am-alteration with dissem py, ccp, (mag). } \\
\text { Mo assoc with ser (pl)-ep-am }\end{array}$ & 7 & 0.058 & $784 \pm 8$ \\
\hline \multirow{2}{*}{ Sm1022-140.8 } & Bt-(am) gneiss & $\begin{array}{l}5 \mathrm{~cm} \text { wide qtz-fsp-ep-zeo-vein rich in mag-py-ccp and with inclusions of ccp } \\
\text { and Mo in coarse py }\end{array}$ & 8 & 0.010 & $92 \pm 5$ \\
\hline & Bt-(am) gneiss & $\begin{array}{l}5 \mathrm{~cm} \text { wide qtz-fsp-ep-zeo-vein rich in mag-py-ccp and with inclusions of ccp } \\
\text { and Mo in coarse py }\end{array}$ & 15 & 0.005 & $467 \pm 53$ \\
\hline Sm1012-128.9 & Am-bt gneiss & $\begin{array}{l}\text { Qtz-fsp-altered with } 3 \mathrm{~mm} \text { wide kfs-qtz-vein containing sparse ccp, mag, } \\
\text { Mo. Mo assoc with kfs }\end{array}$ & 9 & 0.006 & $60 \pm 6$ \\
\hline \multirow{2}{*}{ Sm1022-138.3 } & Bt-(am) gneiss & $\begin{array}{l}1 \mathrm{dm} \text { of qtz-am-ep-mag-ccp-py-alteration rich in fine grained Mo. Mo assoc } \\
\text { with py }\end{array}$ & 10 & 0.037 & $1587 \pm 25$ \\
\hline & Bt-(am) gneiss & $\begin{array}{l}1 \mathrm{dm} \text { of qtz-am-ep-mag-ccp-py-alteration rich in fine grained Mo. Mo assoc } \\
\text { with am-qtz and intergrown with ccp }\end{array}$ & 11 & 0.086 & $1468 \pm 119$ \\
\hline
\end{tabular}


Table 1. Cont.

\begin{tabular}{|c|c|c|c|c|c|}
\hline Sample code (Mo) & Host rock & Sample description & $\begin{array}{l}\text { Sample code } \\
(\mathbf{R e})\end{array}$ & $\begin{array}{l}\text { MoS2 weight } \\
\text { (mg) }\end{array}$ & $\begin{array}{c}\text { Calc Re abundance } \\
\text { (ppm) }\end{array}$ \\
\hline \multirow{3}{*}{ Am947-352.0 } & Qtz monzo-diorite & $\begin{array}{l}\text { Am-ep-qtz-alteration with mag-py-ccp dissem Mo assoc with } \\
\text { ep-(am-qtz-ccp) }\end{array}$ & 12 & 0.006 & $133 \pm 13$ \\
\hline & Qtz monzo-diorite & $\begin{array}{l}\text { Am-ep-qtz-alteration with mag-py-ccp dissem Mo assoc with } \\
\text { qtz-(am-ep-py) }\end{array}$ & 13 & 0.034 & $284 \pm 5$ \\
\hline & Qtz monzo-diorite & $\begin{array}{l}\text { Am-ep-qtz-alteration with mag-py-ccp dissem Mo assoc with } \\
\text { am-(ep-qtz-ccp) }\end{array}$ & 14 & 0.002 & $43 \pm 13$ \\
\hline \multirow{2}{*}{ Am652-518.4 } & Bt-ms schist & $\begin{array}{l}\text { Qtz-kfs-ser-(tur)-alteration with a weak dissem of ccp-(py,mag), sporadic } \\
\text { cm-wide qtz-fsp-veins (brittle, drusy), and a rich } \\
\text { Mo-impreg. Mo assoc with qtz-kfs-ser }\end{array}$ & 18 & 0.007 & $191 \pm 15$ \\
\hline & Bt-ms schist & $\begin{array}{l}\text { Qtz-kfs-ser-(tur)-alteration with a weak dissem of ccp-(py,mag), sporadic } \\
0.5 \mathrm{~cm} \text { wide qtz-fsp-veins (brittle, drusy), and a rich Mo-impreg. Mo assoc } \\
\text { with qtz-kfs-ser }\end{array}$ & 19 & 0.018 & $742 \pm 23$ \\
\hline Agm751-246.7 & Qtz monzo-diorite & $\begin{array}{l}3 \mathrm{~cm} \text { wide am-zeo-ccp-py-Mo-bearing qtz-clot. Mo assoc with } \\
\text { am-qtz-zeo-ccp }\end{array}$ & 20 & 0.018 & $133 \pm 4$ \\
\hline Am947-356.9 & Qtz monzo-diorite & $\begin{array}{l}\text { Am-kfs-(ser)-alteration with ccp, py, Mo. Mo assoc with } \\
\text { am-(kfs) }\end{array}$ & 21 & 0.001 & $84 \pm 49$ \\
\hline Agm878-436.6 & Bt-(am) schist & $0.5 \mathrm{~cm}$ wide qtz-ccp-py-mag-Mo-vein. Mo grain situated between qtz and py & 22 & 0.005 & $48 \pm 6$ \\
\hline \multirow{2}{*}{ Sgm1021-153.2 } & Am-bt gneiss & $\begin{array}{l}1 \mathrm{dm} \text { am-qtz-ccp-py-mag-clot with Mo. Mo assoc with } \\
\text { am-(ccp?) }\end{array}$ & 23 & 0.001 & $367 \pm 208$ \\
\hline & Am-bt gneiss & $\begin{array}{l}1 \mathrm{dm} \text { am-qtz-ccp-py-mag-clot with Mo. Mo assoc with } \\
\text { am-(mag?) }\end{array}$ & 24 & 0.003 & $46 \pm 9$ \\
\hline P-NS & Pegmatite in ms schist & $\begin{array}{l}\text { Folded, N-S trending (parallel to main foliation). Composed of kfs-qtz-ms- } \\
\text { (tur) with accessory ccp, Mo. Mo assoc with coarsegrained ms and kfs }\end{array}$ & 25 & 0.088 & $61 \pm 0.4$ \\
\hline \multirow{2}{*}{ Sg1025-112.4 } & Bt gneiss & $\begin{array}{l}\text { Kfs-qtz-chl-alteration with dissem and intergrown ccp, mag, py, dissem Mo, } \\
\text { and ccp-mag-bearing qtz-veins. Mo assoc with kfs in matrix }\end{array}$ & 26 & 0.039 & $223 \pm 3$ \\
\hline & Bt gneiss & $\begin{array}{l}\text { Kfs-qtz-chl-alteration with dissem and intergrown ccp, mag, py, dissem Mo, } \\
\text { and ccp-mag-bearing qtz-veins. Mo assoc with bt in matrix }\end{array}$ & 27 & 0.013 & $63 \pm 3$ \\
\hline
\end{tabular}


Figure 6. Rhenium concentrations within Aitik (A) and Salmijärvi (S) molybdenite grains. Sample numbers are given at the top of each bar; (a) Rhenium concentration of molybdenite versus molybdenite-bearing host rock; (b) Rhenium concentration of molybdenite versus associated alteration- and ore mineral assemblage. Abbreviations: qtz-quartz, bt-biotite, am-amphibole, ms-muscovite, kfs-K feldspar, chl-chlorite, cal-calcite, ser-sericite, tur-tourmaline, fsp-feldspar, ep-epidote, zeo-zeolite, pl-plagioclase, ccp-chalcopyrite, mag-magnetite, py-pyrite, pegm-pegmatite.

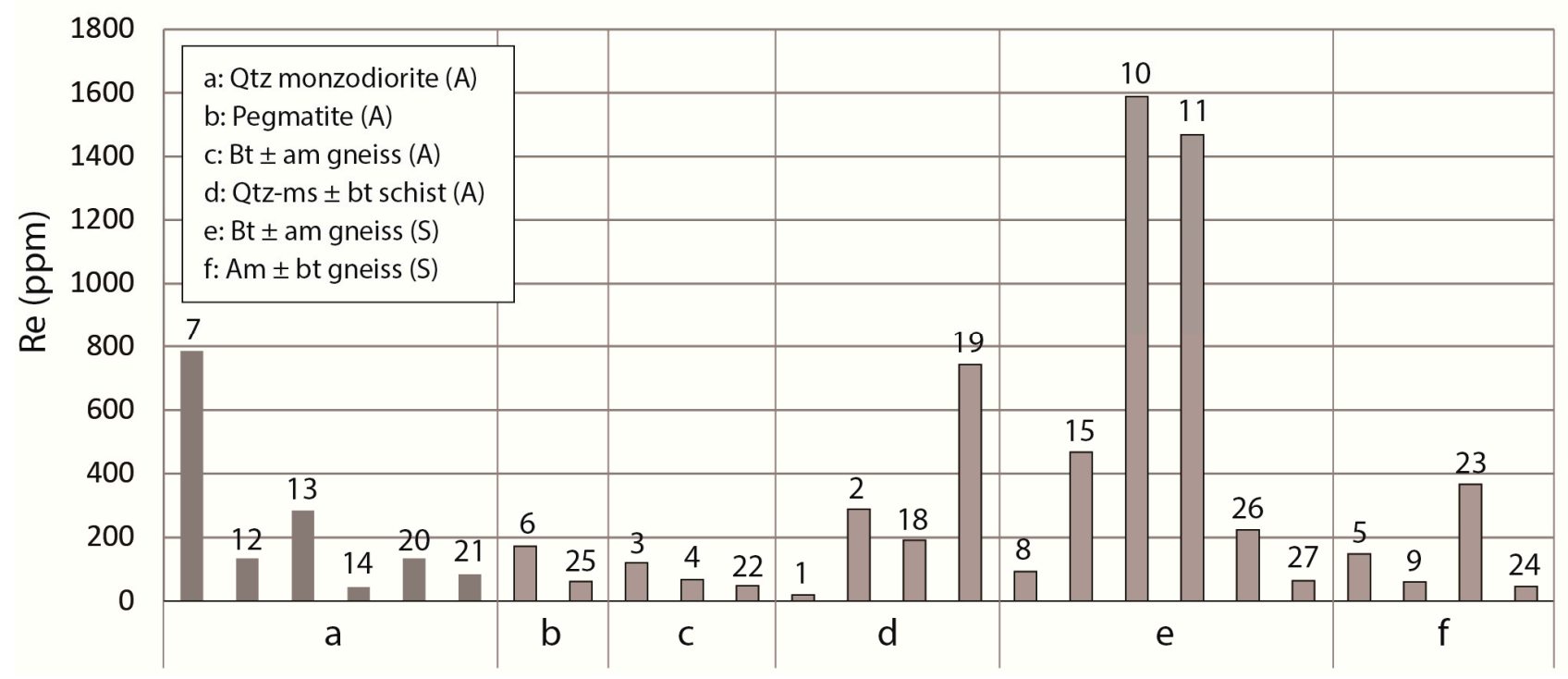

(a)

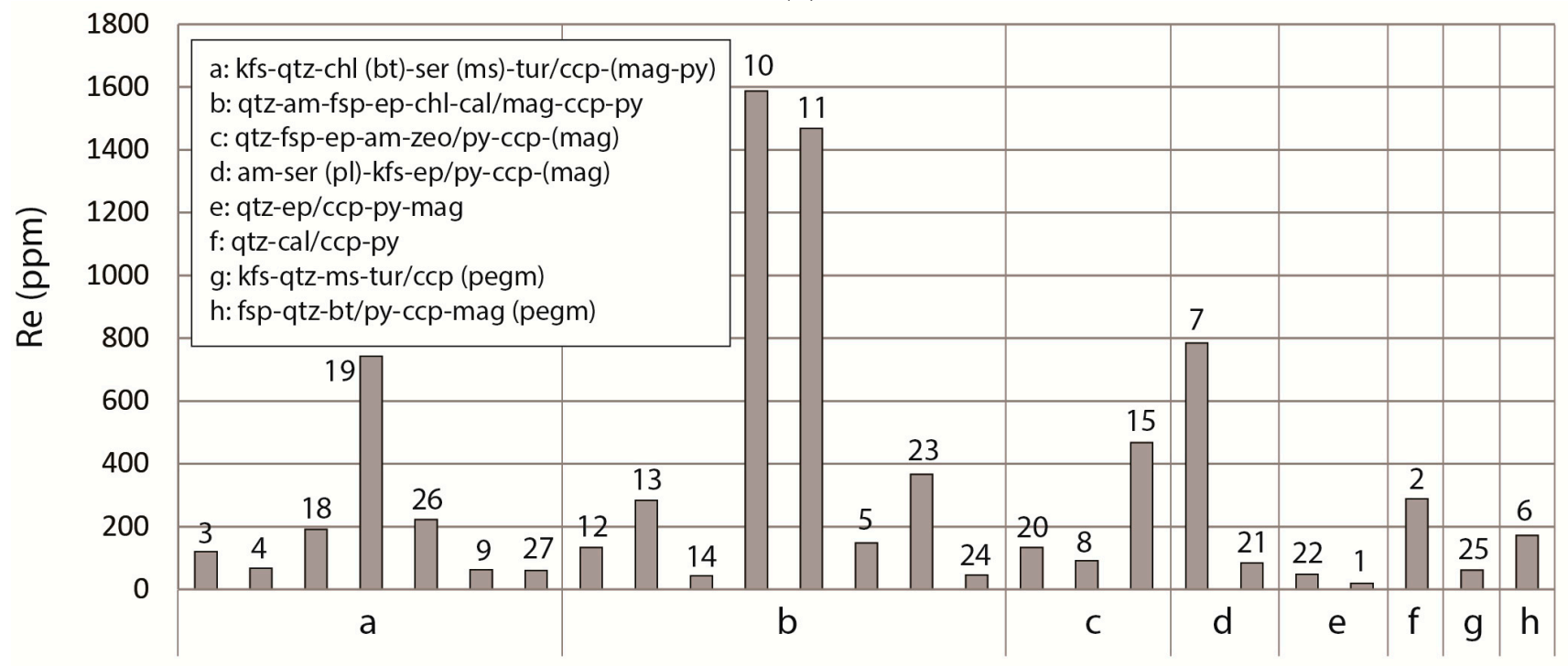

(b)

In Aitik, the Re content of all molybdenite grains associated with sericite (either sericite replacing plagioclase in the quartz monzodiorite or sericite replacing muscovite in the quartz-muscovite schist) are high (commonly above average) and ranges from 191 to $784 \mathrm{ppm}$ (alteration assemblage groups a and $d$ in Figure 6b), whereas the rhenium content of molybdenite grains associated with quartz-(kf-am) ranges from 20 to 289 ppm (alteration assemblage groups a-c, e and $\mathrm{f}$ in Figure 6b). In Salmijärvi, the rhenium content of all molybdenite grains associated with a quartz-amphibole-magnetite alteration 
assemblage, with or without other minerals such as feldspar, chlorite, calcite, epidote, and zeolite, are high (commonly above average) and ranges from 367 to $1587 \mathrm{ppm}$ (alteration assemblage groups b and $\mathrm{c}$ in Figure $6 \mathrm{~b}$ ), whereas the rhenium content of molybdenite grains associated with $\mathrm{K}$ feldspar, biotite, and amphibole ranges from 46 to $223 \mathrm{ppm}$ (alteration assemblage groups a-c in Figure 6b).

\subsection{Molybdenum Flotation}

The Mo recovery after $11 \mathrm{~min}$ grinding time did not substantially differ from that achieved after 7 min grinding time. The laboratory test Mo total recoveries resemble the plant recoveries to the $\mathrm{Cu}$ concentrate. The laboratory total recoveries are presented in Figure 7. Production results representing daily Mo recovery to $\mathrm{Cu}$ concentrate from nearly 2.5 years of production is presented in the same figure as limitation curves for high and low results. The expected Mo recovery is shown also. Three drill core samples with low Mo recoveries are marked out in the figure with the two last digits in the TMP sample number. These are nos. S-6792, S-6783 and S-6786. Three drill core samples with high Mo recoveries are also marked out (sample nos. S-6780, S-6785 and S-6789). The flotation recoveries together with a geological description of each test sample are presented in Table 2.

Figure 7. Molybdenum recoveries at $6 \% \mathrm{Cu}$ rougher concentrate grade and Aitik normal (thick line), high (medium line) and low (thin line) production results. Laboratory data consists of mean values of the tests at 7 and 11 min of grinding. Plant data represents daily Mo recovery to copper concentrate from nearly 2.5 years of production (11 May 2006 to 15 October 2008). Numbers represent the two last digits in the sample numbers presented in Table 2 below.

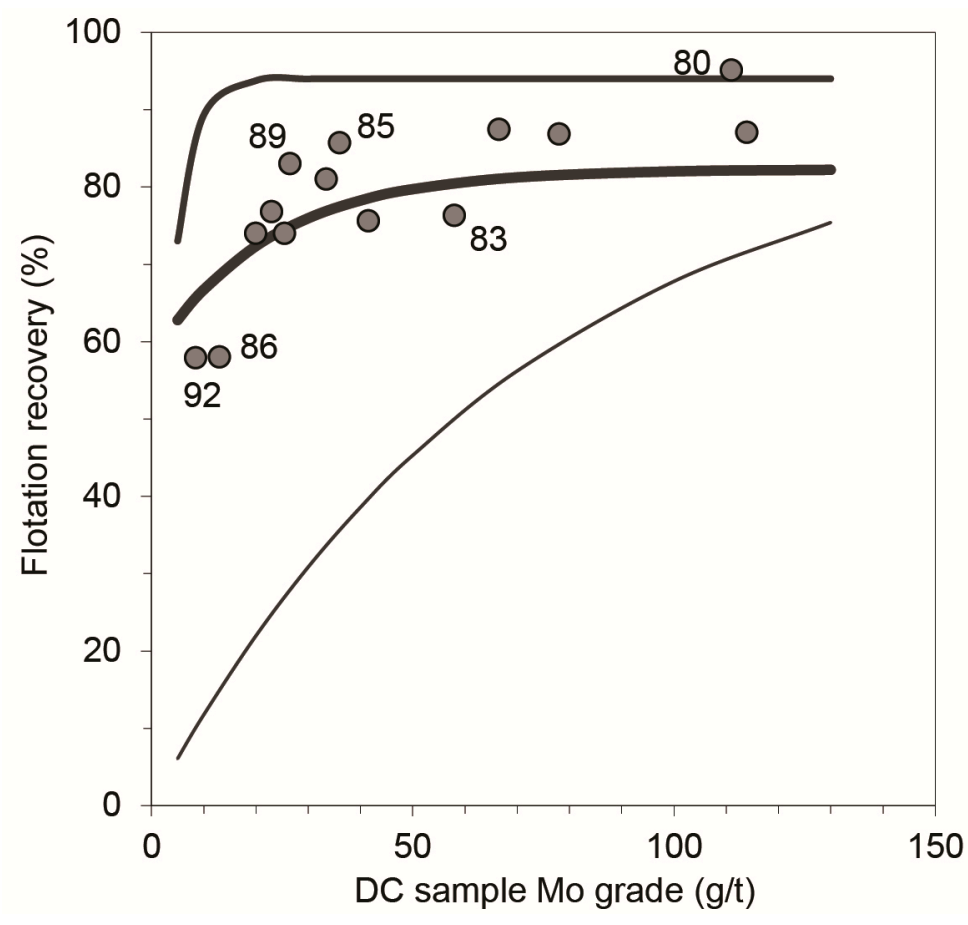


Table 2. Drill core flotation test samples, listed after Mo flotation recovery, difference from average.

\begin{tabular}{|c|c|c|c|c|}
\hline \multicolumn{2}{|c|}{ Sample } & \multirow{2}{*}{$\begin{array}{c}\text { Mo DC-grade } \\
\text { g/t }\end{array}$} & \multirow{2}{*}{$\begin{array}{l}\text { Mo recovery } \\
\text { difference }\end{array}$} & \multirow{2}{*}{ Sample description } \\
\hline Name & TMP No. & & & \\
\hline Aan953-1B & S-6780 & 111 & $13 \%$ & $\begin{array}{l}\text { Slightly am-qtz-ep-altered qtz-monzodiorite with } \\
\text { ccp-py-mag, ccp sometimes intergrown with py }\end{array}$ \\
\hline Aan1055-3A & S-6785 & 36 & $8 \%$ & Unaltered bt gneiss with ccp-mag \\
\hline Aan641-3B & S-6789 & 26 & $8 \%$ & $\begin{array}{l}\text { Strongly ep-chl-ttn-ser-altered am-fsp-bt gneiss with } \\
\text { mag-py-(ccp), ccp often as inclusions in py, which is } \\
\text { bordered by mag }\end{array}$ \\
\hline Aan1110-1B & S-6781 & 66 & $6 \%$ & $\begin{array}{l}\text { Strongly kf-ser-chl-altered qtz-monzodiorite with thin } \\
\text { qtz-veins and ccp-mag-py, commonly intergrown with } \\
\text { each other }\end{array}$ \\
\hline Aan953-1A & S-6779 & 78 & $5 \%$ & $\begin{array}{l}\text { Slightly ser-altered qtz-monzodiorite with ccp-mag-py, } \\
\text { ccp commonly intergrown with mag }\end{array}$ \\
\hline Aan1080-3C & S-6791 & 114 & $5 \%$ & Slightly qtz-tur-altered bt gneiss with ccp-py-mag \\
\hline Aan990-3C & S-6790 & 33 & $4 \%$ & $\begin{array}{l}\text { Slightly kfs-altered bt gneiss with rich ccp-py-po } \\
\text { dissemination }\end{array}$ \\
\hline Aan1045-3B & S-6787 & 23 & $3 \%$ & $\begin{array}{l}\text { Strongly kfs-qtz-ep-tur-altered bt schist with } \\
\text { po-ccp-(py) }\end{array}$ \\
\hline Aan1064-2A & S-6782 & 20 & $2 \%$ & $\begin{array}{l}\text { Moderately grt-mag-qtz-altered ms-(bt) schist with } \\
\text { mag-ccp-py }\end{array}$ \\
\hline Aan1064-3B & S-6788 & 26 & $-1 \%$ & Moderately am-ep-qtz-altered bt schist with py-po-ccp \\
\hline Aan1069-2B & S-6784 & 42 & $-3 \%$ & $\begin{array}{l}\text { Moderately chl-qtz-ser-altered ms-bt-qtz schist with } \\
\text { py-ccp-po, ccp intergrown with po }\end{array}$ \\
\hline Aan1186-2B & S-6783 & 58 & $-4 \%$ & $\begin{array}{l}\text { Strongly ser-chl (1) and kfs-qtz-ep (2) altered ser-bt-chl } \\
\text { schist with py-ccp }\end{array}$ \\
\hline Aan1084-4 & S-6792 & 8 & $-7 \%$ & $\begin{array}{l}\text { Strongly ser-chl-kfs-qtz-altered fsp-bt gneiss with } \\
\text { py-ccp-mag, intergrown py }+ \text { ccp commonly rimmed } \\
\text { by mag }\end{array}$ \\
\hline Aan732-3A & S-6786 & 13 & $-11 \%$ & Moderately qtz-altered bt gneiss with mag-py-ccp \\
\hline
\end{tabular}

qtz: quartz; ms: muscovite; bt: biotite; ser: sericite; chl: chlorite; am: amphibole; fsp: feldspar; ep: epidote; ttn: titanite (sphene); kfs: K feldspar; tur: tourmaline; grt: garnet; ccp: chalcopyrite; mag: magnetite; py: pyrite; po: pyrrhotite.

\section{Discussion}

Porphyry systems are the most important source for molybdenum and rhenium in the world. These deposits alone account for more than $95 \%$ of molybdenum production [19]. Based on the relative content of copper and molybdenum, the porphyry deposits are divided into two categories: $\mathrm{Cu} \pm \mathrm{Mo}$ deposits and $\mathrm{Mo} \pm \mathrm{Cu}$ deposits [20]. In the copper dominant systems the molybdenum grade generally ranges from $0.005 \%-0.03 \%$, while in the molybdenum dominant it ranges from $0.07 \%-0.3 \%[19,21]$.

The rhenium concentration in molybdenite in porphyry systems varies from the ppb level to thousands of ppm [22,23]. In Figure 8, the average rhenium content in the Aitik and Salmijärvi ore bodies are compared with those reported from other porphyry $\mathrm{Cu}$ and $\mathrm{Cu}-\mathrm{Mo}$ deposits in the world. These deposits exhibit a relatively low quantity of molybdenite, and generally contain higher concentrations of rhenium than porphyry Mo-Cu deposits with abundant molybdenite. This may relate 
to the fact that small amounts of molybdenite will consume the limited rhenium budget from the ore-forming fluids whereas rhenium within large volumes of molybdenite-rich magma will be relatively diluted $[14,24,25]$. The Aitik and Salmijärvi deposits show similar trends in Re grades as $\mathrm{Cu}-\mathrm{Mo}$ deposits in general (Figure 8).

Figure 8. Rhenium grades in porphyry $\mathrm{Cu}$ and $\mathrm{Cu}-\mathrm{Mo}$ systems worldwide. Modified from [22].

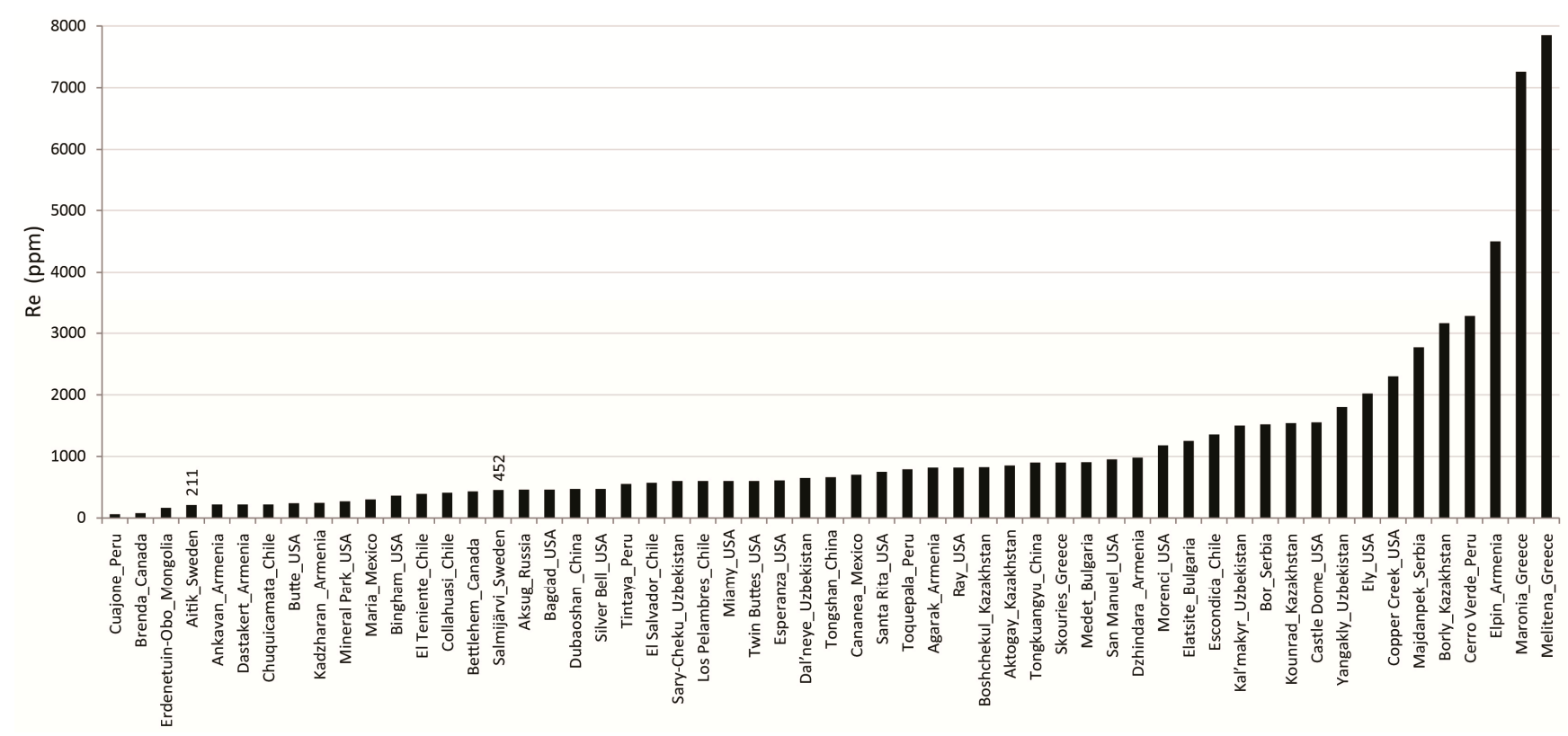

In Aitik, with its complex multi-magmatic/hydrothermal history [3], molybdenum has probably been introduced by several generations of magma, as indicated by Re-Os ages of 1.87, 1.85, and $1.73 \mathrm{Ga}$ obtained for molybdenite in barite and pegmatite dykes in the Aitik ore zone [9]. These ages correspond to the Haparanda, Jyryjoki, and TIB2 magmatism, respectively, which are well-constrained magmatic events in northern Fennoscandia [26]. However, some molybdenite formation might also be the result of late hydrothermal activity and metamorphism. The authors of [27] describe a metamorphic dehydration process active in northern Sweden during the Svecofennian orogeny which produced small Mo-(W) occurrences with characteristic low-Re molybdenite formation. The Liikavaara $\mathrm{Cu}-\mathrm{Au}$ occurrence, situated only $4 \mathrm{~km}$ east of Aitik, contains molybdenite- and scheelite-bearing quartz- and aplitic veins [28]. Its close spatial relationship to Aitik implies that fluids responsible for the Liikavaara Mo-W mineralization might also have affected the Aitik deposit and its southern extension, with possible addition of (low-Re) molybdenite as a result.

Regarding the distribution of molybdenite within the Aitik ore body, molybdenum grades are higher in the northern part of the ore body than in the southern part (Figure 9). One explanation to this pattern may be the distribution of variably altered host rocks, since certain alteration types and associated veining, rather than a specific rock type, seems to be an important factor controlling the distribution of molybdenite in Aitik.

The majority of studied molybdenite grains are found within mica schists and quartz monzodiorite, and coarser molybdenite grains $(>50 \mu \mathrm{m})$ are exclusively found in samples of these rock types (Figure 4). The mica schists, and especially the quartz-muscovite-(sericite) schist, are nearly absent 
towards the south and towards depth (Figure 2), thus partly explaining the large-scale distribution pattern (Figure 9).

Figure 9. Contoured grade map of Mo at the $300 \mathrm{~m}$ level in the Aitik deposit. Grades are taken from the block model of the Aitik mine, and based on $c a$. 15,000 Mo analysis of drill core sections.

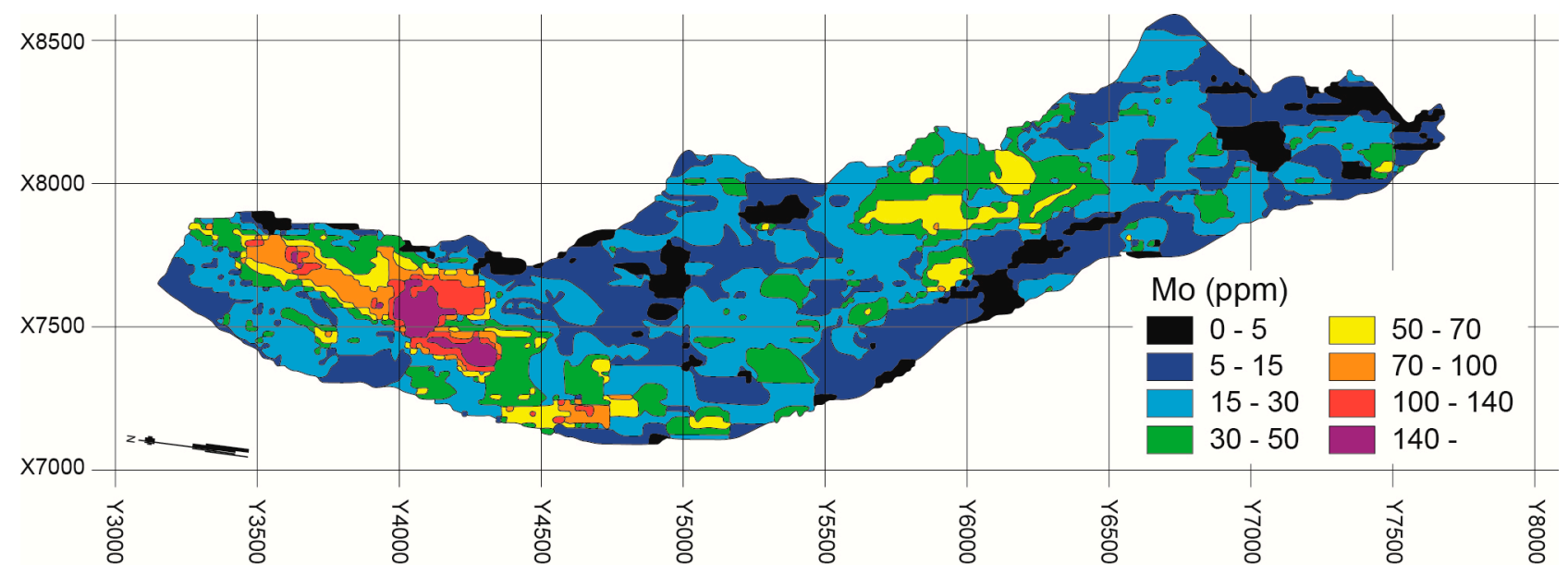

The quartz monzodiorite is the source intrusion to the Aitik mineralization [7] and the mica schists and gneiss are co-magmatic volcanosedimentary rocks that have been strongly altered and deformed [8]. Molybdenite mineralization in porphyry ore systems often occurs after the main $\mathrm{Cu}$-Au mineralizing event [29]. In a recent study of the Bingham porphyry deposit, [30] describes a process of selective metal deposition from a magmatic fluid due to changes of redox and $\mathrm{pH}$ conditions associated with a more reducing environment in the fluid source. The molybdenite mineral associations revealed in this study however indicate opposite conditions (e.g., anhydrite, magnetite, see discussion below). Contrary to the more common Phanerozoic porphyry systems the Aitik and Salmijärvi ore bodies have been subjected to at least two metamorphic events, varying degrees of multiple deformation, and an overprinting hydrothermal event of IOCG-type [3], and the distribution and character of ore minerals as seen today is probably more the result of a combination of post-ore processes including recrystallization, remobilization, and mineral/element differentiation, rather than primary features. These processes are known to lead to both concentration and dispersion of valuable minerals and also to considerable variations in ore grade within a single deposit [31].

As mentioned above, molybdenite in Aitik is found in a wide variety of mineralogical associations, although an association with anhydrite dominates together with chalcopyrite, pyrite, biotite, $\mathrm{K}$ feldspar, pegmatite dykes, and barite- and quartz veins. The surprisingly strong association with anhydrite instead of expected quartz indicates that there might be more anhydrite in the deposit than previously thought, i.e., that anhydrite is mistaken for quartz/feldspar-alteration and veining when drill cores are being logged.

Molybdenite in Salmijärvi is dominantly associated with pegmatite dykes and late $\mathrm{K}$ feldsparepidote-quartz \pm magnetite-alteration of the gneisses. The richest sample, containing 538 molybdenite grains, is a $\mathrm{K}$ feldspar-altered biotite gneiss with sporadic sulfide-magnetite-apatite-alteration patches of typical IOCG-character (iron-oxide copper gold). The size of molybdenite grains in Salmijärvi is 
significantly larger than those found in Aitik (Figure 5), a feature that might be caused by the slightly higher grade of metamorphism implied for the Salmijärvi area [13]. In Salmijärvi, a coarsening of the molybdenite grain size seems to follow the degree of alteration, with the overprinting sulfide-magnetite-apatite-alteration containing most of the coarser grains. The relationship between grain size and alteration type, with grains $\leq 10 \mu \mathrm{m}$ mainly associated with $\mathrm{K}$ feldspar, quartz, and biotite, and grains 10-185 $\mu \mathrm{m}$ associated with chalcopyrite, pyrite, magnetite, $\mathrm{K}$ feldspar, quartz, biotite, and apatite, indicates that even if the latter mineral association is not the most common one, it probably constitutes the largest mass of molybdenite due to the larger grain size, an observation with relevance for future processing of the ore. The strong alteration is of oxidized character, occasionally rich in goethite and magnetite, which gives the rock an easily recognized rusty red color. This alteration type has not been observed in the Aitik ore body.

It is clear that strong alteration and post-ore veins of variable composition, often in combination with patches and clots of remobilized $\mathrm{Cu}-\mathrm{Fe}$ sulfides appear to favor the occurrence of molybdenite in Aitik and Salmijärvi. This is probably related to the hydrothermal fluid that causes the alteration, in combination with deformation, both of which would allow molybdenum to migrate [32]. Thus, less molybdenite is found in the biotite gneiss, which is less altered and less tectonically affected than the mica schists, an observation also made in the Archaean $\mathrm{Cu}$-Au-Mo occurrences of the Chibougamau district, Québec [33].

In Aitik molybdenite, with an average rhenium concentration of $211 \mathrm{ppm}$, molybdenite hosted by quartz monzodiorite and quartz-muscovite-sericite schist generally contain higher concentrations of rhenium (on average 244 and 310 ppm, respectively) than those hosted by pegmatites and gneisses (on average 116 and $157 \mathrm{ppm}$, respectively). In fact, the rhenium content of all studied molybdenite grains associated with sericite, either sericite replacing plagioclase in the quartz monzodiorite or sericite replacing muscovite in the quartz-muscovite schist, are high (commonly above average) and ranges from 191 to $784 \mathrm{ppm}$, whereas the rhenium content of molybdenite grains associated with quartz-(K feldspar-amphibole) ranges from 20 to $289 \mathrm{ppm}$. The variation of rhenium in molybdenite from the Sar Cheshmeh porphyry Cu-Mo deposit, Iran, shows an increased rhenium concentration in molybdenite that is intimately associated with sericitic altered veins of low quartz content, whereas a low rhenium concentration is obtained for molybdenite in quartz veinlets showing strong silicification [34]. Other observations note high-rhenium in quartz-sericite-altered (phyllic) rocks and low-rhenium in K-feldspar/biotite-altered (potassic) rocks, and suggest an inverse relationship between the temperature of formation and the Re content of molybdenite [22]. Similar observations were made of molybdenite from the Bingham deposit [24]. As such, high-temperature, magmatic fluid may form low-rhenium molybdenite, similar to those grains analyzed from Aitik pegmatites and quartz-(-feldspar-amphibole)-clots, and a low-temperature, hydrothermal/metamorphic fluid could generate high-rhenium molybdenite such as the grains analyzed from Aitik muscovite-sericite schist and strongly sericite-altered quartz monzodiorite.

A similar pattern, although with molybdenite associated with a different mineral assemblage, is found in Salmijärvi where the rhenium content of all molybdenite grains associated with quartz-amphibole-magnetite alteration, with or without other minerals such as feldspar, chlorite, calcite, epidote, and zeolites, is high (commonly above the average $452 \mathrm{ppm}$ ) and ranges from 367 to 1587 ppm, whereas the rhenium content of molybdenite grains associated with $\mathrm{K}$ feldspar, biotite, and 
amphibole ranges from 46 to $223 \mathrm{ppm}$. This magnetite-rich alteration is common in Salmijärvi and Aitik and in many other metal-rich occurrences in the northern Norrbotten ore district (e.g., Nautanen and Tjårrojåkka) and is linked to the overprinting hydrothermal event of IOCG-type observed in the region [3]. Oxidizing fluids, which are favorable for transport of rhenium [35], might thus be partly responsible for deposition of high-rhenium molybdenite in Salmijärvi and Aitik, and just as with the distribution of molybdenite, certain alteration types rather than specific rock types can be of guidance when documenting the overall rhenium abundance in molybdenite-bearing deposits.

Molybdenite from two generations of pegmatite dykes analyzed in this study revealed a much lower rhenium concentration for molybdenite within the old $(c a .1 .85 \mathrm{Ga})$ and deformed pegmatite dyke, than for molybdenite within the young $(c a .1 .73 \mathrm{Ga})$ and cross-cutting pegmatite dyke (Table 1, Figure 6). The concentrations obtained (61 and $172 \mathrm{ppm}$, respectively) are in reasonable agreement with rhenium concentrations measured for Re-Os geochronological studies of the same pegmatite dykes by [9] giving values of 54 and 215 ppm, respectively. The concentration of rhenium in molybdenite is known to be a combination of several interplaying factors, e.g., composition of parent magmas and host rocks [14,22,36], degree of oxygen and chloride fugacity of the ore fluid [37], and changes in chemical and physical conditions during crystallization [22]. Reference [38] in their study of molybdenite in the Archaean Boddington $\mathrm{Cu}$-Au deposit, Western Australia, also suggest that even though rhenium can remain locked in molybdenite under deformation, dissolution and reprecipitation may occur giving molybdenite a different rhenium concentration and grain size.

\section{Processing Implications}

Molybdenum is commonly recovered from copper concentrates in a process that starts with dewatering prior to the molybdenum circuit to get rid of excess reagents, followed by conditioning with a depressor for copper. The most common depressor is NaHS, sometimes in combination with cyanide. Finely ground activated carbon can be used to further remove excess of reagents and higher temperatures are sometimes used to promote the removal of collectors. Oxygen destroys the depressor to some extent and is avoided by using, e.g., nitrogen as the flotation gas. Regrinding of intermediate concentrates is normal to get better liberation and to make the froth easier to pump. Conventional flotation cells are used for rougher and scavenger flotation and quite often also for the first cleaners. Since the introduction of columns in the early 80's, more or less every molybdenum circuit has columns for the last cleaning steps. Due to the flaky character of molybdenite grains, with strong hydrophobic and inert faces and hydrophilic and reactive edges, additions of fuel oils to enhance the flotation is common practice. Molybdenum extraction from the molybdenite concentrate is performed by roasting of molybdenite at a temperature of $500-700{ }^{\circ} \mathrm{C}$. During this process the molybdenum transforms to molybdenum trioxide and the rhenium stored within molybdenite transforms to rhenium heptoxide gas $\left(\mathrm{Re}_{2} \mathrm{O}_{7}\right)$ [39]. The molybdenum recovery obtained by this process is less than $93 \%$, generally ranging between $25 \%-85 \%$ [40].

The volatilized rhenium can be caught using a wet electrostatic system combined with dry apparatus, and transferred to a solution containing sulfuric acid, which leaches the rhenium from the enriched flue dust [39]. The separation of rhenium from this solution is achieved by sorption using ion-exchanges resins and/or liquid extraction [39,41] followed by addition of potassium chloride and 
ammonium chloride in order to precipitate or isolate rhenium elution in the form of perrhenate salts. The non-hazardous and stable ammonium perrhenate $\left(\mathrm{NH}_{4} \mathrm{ReO}_{4}\right)$ is the common market product of rhenium. The rhenium recovery obtained by this process is generally less than $60 \%$ [40].

\section{Mo Extraction}

The possibility to recover molybdenum from the copper concentrate at Aitik has been investigated several times during the lifetime of the mine. The normal procedure with depression of chalcopyrite and other sulfides with NaHS as described in the previous section, has been proven to work for the Aitik concentrate [42].

However, even if Mo assays are obtained fast enough to be of guidance in process regulations (which is often not the case) they might not provide an accurate indication of recoverable molybdenum as long as factors influencing the extraction process are not defined and taken into account. In the current study, where one focus has been to identify lithological and mineralogical factors in the incoming ore which might affect molybdenum recovery, flotation laboratory tests reveal that three drill core samples resulting in Mo-recoveries lower than expected $(-4 \%$ to $-11 \%)$ considering the drill core Mo grades are from two different rock types (Table 2): feldspar-biotite gneiss and biotie gneiss. These samples have three characteristics in common (1) they contain $30 \%-50 \% \mathrm{Fe}-\mathrm{Mg}$ micas (2) they contain rare quartz veinlets, and (3) they contain molybdenite grains of dominantly less than $10 \mu \mathrm{m}$ size. QEMSCAN data of sample Aan1186-2B reveal that most mica is phlogopite, the Mg-rich end member of the biotite group. Chlorite in the same sample is of chamosite-composition (a Mg-Fe-rich member of the chlorite group), and a significant part of the minerals end up as unidentified Mg-minerals (Figure 10). Furthermore, 63\% of detected molybdenite grains are less than $10 \mu \mathrm{m}$. QEMSCAN data from four samples taken only 16-17 m downhole from Aan732-3A contain 445 molybdenite grains where $93 \%-100 \%$ are less than $10 \mu \mathrm{m}$.

In sample Aan1064-2A, giving a Mo-recovery almost as expected (+2\%), approximately the same amount of mica is present (45\%), although in the form of annite (Fe-biotite) and muscovite (Figure 10). It is known that fine-grained mica minerals can disturb the flotation process by interfering in the separation of chalcopyrite and molybdenite [43]. Results from this study indicate that the mica composition may also be of significance. According to [44], there are four non-sulfide minerals in the Bingham Mine, Utah, that are negatively correlated with molybdenum recovery: talc, andradite, calcite and amphibole. These minerals contain $\mathrm{Ca}^{2+}$ or $\mathrm{Mg}^{2+}$ or both. Zanin et al. (2009) studied the effect of $\mathrm{Ca}^{2+}$ and $\mathrm{Mg}^{2+}$ in solution and gangue minerals on the recovery of molybdenite by performing laboratory flotation tests on coarse molybdenite particles from two different host rocks. They came to the conclusion that the adsorption of $\mathrm{Ca}^{2+}$ and $\mathrm{Mg}^{2+}$ to the edges of molybdenite particles may have the combined effect of reducing the hydrophobicity of molybdenite grains, and bridging to specific, negatively charged, gangue minerals in the slurry, possibly leading to the formation of slime coatings. The bridging effect was also shown to be dependent on the type of host rock [45].

Reference [44] furthermore identifies biotite/phlogopite as being positively correlated with molybdenum recovery, a finding that are not discussed further by [44], and that is in contrast to results presented in this paper and to the work by [43] where a number of clay-micas (e.g., chamosite) are identified as causing poor molybdenum recovery. 
Some drill core samples produced higher Mo-recoveries than expected. Looking at the three top samples $(+8 \%$ to $+13 \%)$, these also represent different rock types: quartz monzodiorite, biotite gneiss, and amphibole-feldspar-biotite gneiss, but they are all characterized by common quartz veins and quartz clots containing chalcopyrite and pyrite, a feature that is missing in the samples discussed above. The amount of mica minerals is limited in these samples (Figure 10). Furthermore, no molybdenite was found when analyzing thin sections from two of these flotation samples by QEMSCAN. Since molybdenum grades are normal to high (26-111 ppm) in these samples, this probably indicates that the molybdenite is coarse grained and therefore difficult to trap in a thin section.

Figure 10. QEMSCAN diagrams showing the mineralogical composition for Mg-rich (Aan1186-2B), Fe-rich (Aan1064-2A), and mica-poor samples (Aan641-3B).

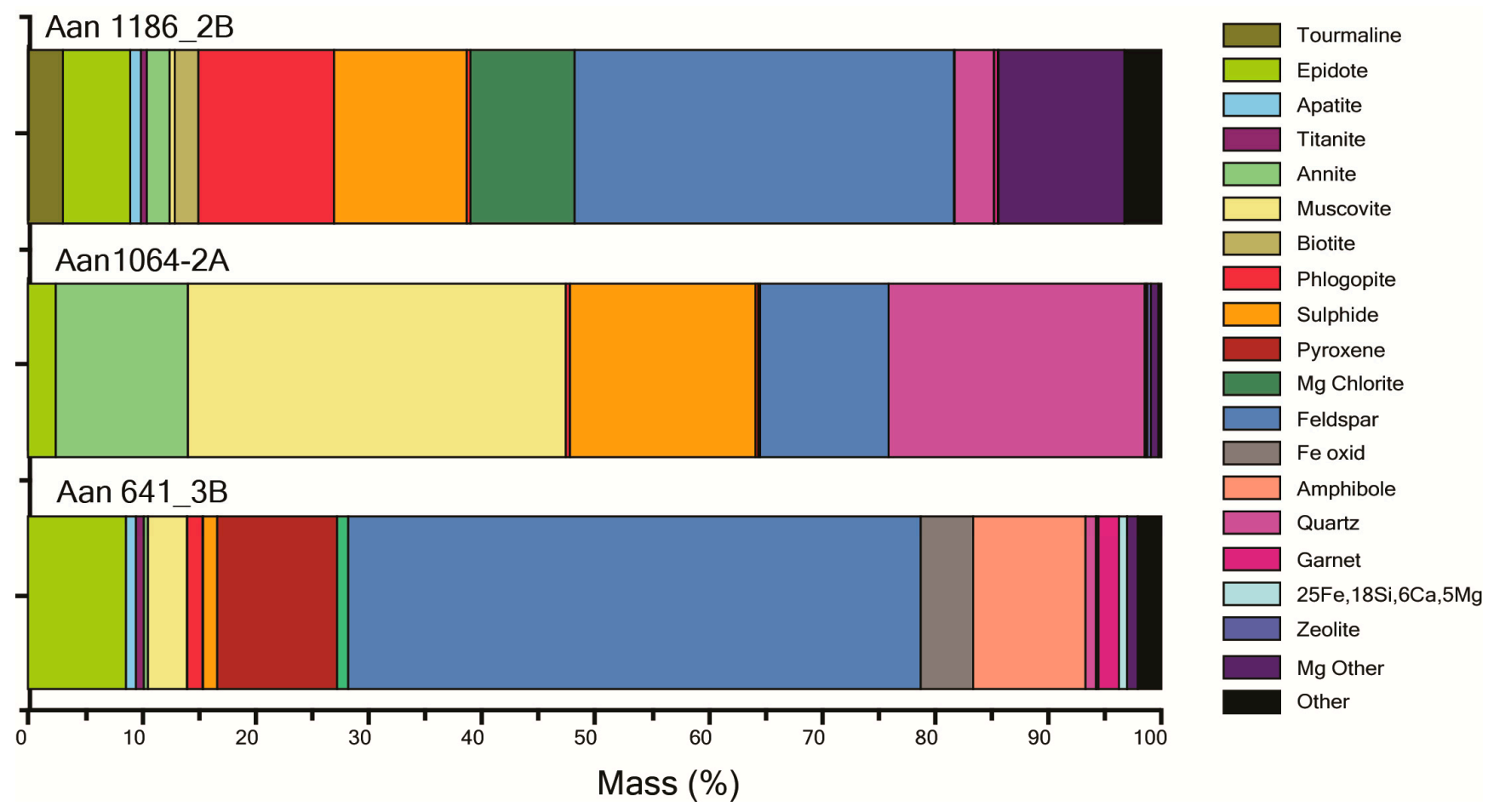

One reason for the obtained results thus seems to be found in the geological and mineralogical character of the rock, i.e., the host rock lithology, the vein- and alteration types present, and the size of molybdenite grains, thus emphasizing the importance of careful characterization of ores, including the distribution and texture of both ore and gangue minerals, in order to develop optimized treatment processes.

\section{Re Extraction}

The possibility to recover rhenium from the molybdenite concentrate at Aitik has never been tested or investigated. As can be seen from the result of this work, the Aitik molybdenite contains on average 213 ppm Re, but this varies considerably between different particles (20-1587 ppm). High-Re molybdenite is mainly found in quartz monzodiorite and quartz-muscovite-sericite schist. The majority of molybdenite grains in Aitik are less than 10 microns though, and the quartz-muscovite-sericite 
schist disappears towards depth and towards south. Regarding the pegmatite dykes, these are due to their hardness occasionally separated from the ore to avoid low throughput. Their molybdenite and rhenium contents, although limited, could form an added value and thus motivate more of such handling, and perhaps change the mine cut-off grade. In Salmijärvi, however, the average Re content is higher (452 ppm), the size of molybdenite grains is larger, and the high-Re molybdenite is found within the common biotite-(amphibole) gneiss.

A mass balance prognosis for molybdenum concentrate production at Aitik is presented in Table 3 . A Mo content of $0.0025 \%$ in the Aitik ore, and a recovery of $c a .85 \%$ to the copper concentrate can be assumed. Furthermore, a $60 \%$ recovery in the Mo circuit from the $\mathrm{Cu}$ concentrate can be assumed based on laboratory and plant scale tests [42]. An annual ore production of $36 \mathrm{Mt}$ will give a production of 1047 tonnes $\mathrm{MoS}_{2}$ concentrate with $53 \% \mathrm{Mo}$, thus a Mo production of 544 tonnes/year. Together with a rough estimation of the rhenium content of the Aitik deposit based on the average rhenium concentration obtained in this study $(213 \mathrm{ppm})$, the current reserve of the deposit $(747 \mathrm{Mt})$, the $\mathrm{MoS}_{2}$ concentrate (1047 tonnes), and a general Re recovery $(60 \%)$, it is obvious that these new products have the potential of increasing the value of the Aitik ore and extend the life of the mine.

Table 3. Mass balance prognosis for molybdenum concentrate production at Aitik.

\begin{tabular}{cccccc}
\hline Product & Weight ktonne & Grade Cu & [\%] Mo & Distribution Cu & [\%] Mo \\
\hline Ore feed & 36,000 & 0.25 & 0.0025 & 100 & 100 \\
Cu conc. & 324 & 25 & 0.2479 & 90 & 85 \\
Mo conc. & 0.849 & 1.6 & 53 & 0.02 & 50 \\
Cu final conc. & 323 & 25.06 & 0.1093 & 89.98 & 35 \\
Final tailing & 35,676 & 0.025 & 0.00027 & 10 & 15 \\
\hline
\end{tabular}

These are good examples demonstrating the importance of transforming qualitative and quantitative micro-scale information about the ore to a larger scale of direct importance for future production. By studying in-situ samples, the important link between analytical data from carefully chosen and examined samples to the character of specific rock volumes within the mine can be established, even if selective mining seldom is used in porphyry ores, information of this kind helps to improve predictions and mine planning.

\section{Conclusions}

Molybdenite in the Aitik area varies considerably in grain size, between the two studied ore bodies and within each ore body, and is dominantly very fine-grained. Most molybdenite grains are found as single grains, as aggregates, or intergrown with chalcopyrite, and are associated with late, post-ore geological features, such as overprinting garnet-magnetite-anhydrite-quartz-K feldspar-apatite-alteration, quartz-veining, and pegmatite dykes. The rhenium concentration of molybdenite varies considerably, with the higher concentrations obtained from Salmijärvi molybdenite samples. The large variation is probably the result of several magmatic/hydrothermal and metamorphic episodes that have been active in the region. The Aitik and Salmijärvi deposits exhibit similar molybdenum and rhenium contents as Mo-Re-producing porphyry Cu-Mo deposits worldwide (e.g., El Teniente and Chuiqicamata in Chile, and Bingham and Copper Creek in USA), and pilot plant tests have shown that recovery for 
molybdenum at Aitik is good compared to other deposits in the world. If molybdenum and rhenium circuits are installed, the price of molybdenum and rhenium in combination with the calculated amount of metal present in the Aitik ore body indicates that the two metals would constitute significant byproducts of copper production in Aitik. The data presented in this study describes the character and distribution of molybdenite in order to help predicting the outcome of this future large investment. The distribution, character, and rhenium concentration of molybdenite within the two investigated ore bodies seems to be related to specific alteration and vein features rather than to rock types, and these features also seem to have an impact on the final recovery of molybdenum. They are thus important to estimate quantitatively for processing and mine planning.

\section{Acknowledgments}

Boliden $\mathrm{AB}$ is acknowledged for the financial support of this study, and for the permission to publish this paper. We would like to thank Björn Johansson, Boliden AB, for the flotation test setup and performance, and Jenny Wikström, LKAB, for assisting with complementary QEMSCAN data. We also thank the external editor and two anonymous reviewers for their constructive comments on the manuscript. Support from the ProMinNET (Nordic Researcher Network in Geometallurgy and Process Mineralogy) researchers is acknowledged. This is a CAMM (Centre of Advanced Mining and Metallurgy) publication.

\section{Author Contributions}

C.W. conceived the study and did the field sampling in Aitik and Salmijärvi. C.W., D.S. and N.-J.B. designed the experiments. C.W., W.N., C.M. and N.-J.B. performed the experiments and analyzed the data together with D.S. and R.N. All authors have contributed to the writing of the manuscript and with the production of figures and tables.

\section{Conflicts of Interest}

The authors declare no conflict of interest.

\section{References}

1. Fleischer, M. The geochemistry of rhenium, with special reference to its occurence in molybdenite. Econ. Geol. 1959, 54, 1406-1413.

2. Martinsson, O.; Wanhainen, $\mathrm{C}$. Fe oxide and $\mathrm{Cu}-\mathrm{Au}$ deposits in the northern Norrbotten ore district. In Proceedings of the 12th Biennial SGA Meeting, Uppsala, Sweden, 12-15 August 2013.

3. Wanhainen, C.; Broman, C.; Martinsson, O.; Magnor, B. Modification of a Palaeoproterozoic porphyry system in northern Sweden: Integration of structural, geochemical, petrographic, and fluid inclusion data from the Aitik Cu-Au-Ag deposit, northern Sweden. Ore Geol. Rev. 2012, 48, 306-331.

4. Wanhainen, C.; Kontturi, M.; Martinsson, O. Copper and gold distribution at the Aitik deposit, Gällivare area, northern Sweden. Appl. Earth Sci. Trans. Inst. Min. Metall. B 2003, 112, 260-267. 
5. Sammelin-Kontturi, M.; Wanhainen, C.; Martinsson, O. Gold mineralogy at the Aitik Cu-Au-Ag deposit, Gällivare area, northern Sweden. GFF 2011, 133, 1-12.

6. Jakobsson, P.; Joslin, G.; Knipfer, S.; Nordin, R.; Wasström, A.; Wanhainen, C. The Aitik porphyry $\mathrm{Cu}-\mathrm{Au}-\mathrm{Ag}-(\mathrm{Mo})$ deposit in Sweden. In Proceedings of the Eleventh Biennal SGA Meeting, Antofagasta, Chile, 26-29 September 2011; pp. 346-347.

7. Wanhainen, C.; Billström, K.; Martinsson, O. Age, petrology and geochemistry of the porphyritic Aitik intrusion, and its relation to the disseminated Aitik $\mathrm{Cu}-\mathrm{Au}-\mathrm{Ag}$ deposit, Northern Sweden. GFF 2006, 128, 273-286.

8. Wanhainen, C.; Martinsson, O. Geochemical characteristics of host rocks to the Aitik $\mathrm{Cu}-\mathrm{Au}$ deposit, Gällivare area, northern Sweden. In Proceeding of the Fifth Biennial SGA Meeting and the Tenth Quadrennial IAGOD Meeting, London, UK, 22-25 August 1999; pp. 1443-1446.

9. Wanhainen, C.; Billström, K.; Martinsson, O.; Stein, H.; Nordin, R. 160 Ma of magmatic/hydrothermal and metamorphic activity in the Gällivare area: Re-Os dating of molybdenite and $\mathrm{U}-\mathrm{Pb}$ dating of titanite from the Aitik $\mathrm{Cu}-\mathrm{Au}-\mathrm{Ag}$ deposit, northern Sweden. Miner. Deposita 2005, 40, 435-447.

10. Wanhainen, C.; Johansson, B. Character of gold within the Aitik Ore body: Preliminary results from a geometallurgical study. In Proceedings of the Conference in Minerals Engineering, Luleå University of Technology, Luleå, Sweden, 5-6 February 2008; pp. 143-150.

11. Monro, D. The Geology and Genesis of the Aitik Copper-Gold Deposit, Arctic Sweden. Ph.D. Thesis, University of Wales, College of Cardiff: Cardiff, United Kingdom, 1988.

12. Nordin, R. Geologisk beskrivning. In Ansökan om Bearbetningskoncession Aitik K nr 4; Gällivare Kommun: Norrbottens län, Sweden, 2005; p. 7. (In Swedish)

13. Sarlus, Z. Geology of the Salmijärvi $\mathrm{Cu}-\mathrm{Au}$ Deposit. Master's Thesis, Luleå University of Technology, Luleå, Sweden, 2012, p. 75.

14. Stein, H.; Markey, R.; Hannah, J.; Schersten, A. The remarkable Re-Os Chronometer in molybdenite: How and why it works. Terra Nova 2001, 13, 479-486.

15. Kosler, J.; Simonetti, A.; Sylvester, P.; Cox, R.; Tubrett, M.N.; Wilton, D. Laser ablation ICP-MS measurements of $\mathrm{Re} / \mathrm{Os}$ in molybdenites and implications for Re-Os geochronology. Can. Mineral. 2003, 41, 307-320.

16. Selby, D.; Creaser, R. Macroscale NTIMS and microscale LA-MC-ICP-MS Re-Os isotopic analysis of molybdenite: Testing spatial restrictions for reliable Re-Os age determinations, and implications for the decoupling of Re and Os within molybdenite. Geochim. Cosmochim. Acta 2004, 68, 3897-3908.

17. Charlier, B.A.; Ginibre, C.; Morgan, D.; Nowell, G.M.; Pearson, D.G.; Davidson, J.P.; Ottley, C.J. Methods for the microsampling and high-precision analysis of strontium and rubidium isotopes at single crystal scale for petrological and geochronological applications. Chem. Geol. 2006, 232, 114-133.

18. Siivola, J.; Schmid, R. Recommendations by the IUGS Subcommission on the Systematics of Metamorphic Rocks: List of Mineral Abbreviations. IUGS Commission on the Systematics in Petrology. Available online: http://www.bgs.ac.uk/scmr/docs/papers/paper_12.pdf (accessed on 24 November 2014).

19. Sinclair, W.D. Porphyry Deposits. Geol. Surv. Can. Spec. Publ. 2007, 5, 223-243. 
20. Kirkham, R.V.; Sinclair, W.D. Porphyry copper, gold, molybdenum, tungsten, tin, silver. In Geology of Canadian Mineral Deposit Types; Eckstrand, O.R., Sinclair, W.D., Thorpe, R.I., Eds.; Geological Survey of Canada: Ottawa, ON, Canada, 1995; pp. 421-446.

21. Singer, D.A.; Berger, V.I.; Moring, B.C. Porphyry Copper Deposits of the World: Database and Grade and Tonnage Models; US Geological Survey Open-File Report; US Geological Survey: Reston, VA, USA, 2008; p. 45.

22. Berzina, A.; Sotnikov, V.I.; Economou-Eliopoulos, M.; Eliopoulos, D.G. Distribution of rhenium in molybdenite from porphyry $\mathrm{Cu}-\mathrm{Mo}$ and $\mathrm{Mo}-\mathrm{Cu}$ deposits of Russia (Siberia) and Mongolia. Ore Geol. Rev. 2005, 26, 91-113.

23. Millensifer, T.A.; Sinclair, D.; Jonasson, I.; Lipmann, A. Chapter 14: Rhenium. In Critical Metals Handbook, 1st ed.; Gunn, G., Ed.; Wiley \& Sons: Hoboken, NJ, USA, 2014; pp. 340-360.

24. Giles, D.L.; Shilling, J.H. Variation in rhenium content of molybdenite. In Proceedings of the 24th International Geological Congress Section, Montreal, QC, Canada, 21-29 August 1972; pp. $145-152$.

25. Sinclair, W.D.; Jonasson, I.R.; Kirkham, R.V.; Soregaroli, A.E. Rhenium and Other Platinum-Group Metals in Porphyry Deposits; Geological Survey of Canada Open-File; Geological Survey of Canada: Ottawa, ON, Canada, 2009.

26. Bergman, S.; Kubler, L.; Martinsson, O. Description of Regional Geological and Geophysical Maps of Northern Norrbotten County; Sveriges Geologiska Undersökning: Uppsala, Sweden, 2001; pp. 5-100.

27. Stein, H. Low-rhenium molybdenite by metamorphism in northern Sweden: Recognition, genesis, and global implications. Lithos 2006, 87, 300-327.

28. Zweifel, H. Aitik: Geological Documentation of a Disseminated Copper Deposit-A Preliminary Investigation; Sveriges Geologiska Undersökning: Uppsala, Sweden, 1976.

29. Sillitoe, R. Porphyry copper systems. Econ. Geol. 2010, 105, 3-41.

30. Seo, J.; Guillong, M.; Heinrich, C. Separation of Molybdenum and Copper in Porphyry Deposits: The Roles of Sulfur, Redox, and pH in Ore Mineral Deposition at Bingham Canyon. Econ. Geol. 2012, 107, 333-356.

31. Vokes, F.M.; Spry, P.G.; Marshall, B. Ores and metamorphism: Introduction and historical perspectives. Rev. Econ. Geol. 2000, 11, 1-18.

32. Marshall, B.; Gilligan, L.B. An introduction to remobilisation: Information from orebody geometry and experimental considerations. Ore Geol. Rev. 1987, 2, 87-131.

33. Kirkham, R.V.; Pilote, P.; Sinclair, W.D.; Robert, F.; Daigneault, R. Merrill Island Cu-Au veins and Clark Lake $\mathrm{Cu}-(\mathrm{Mo})$ porphyry deposit, Doré Lake mining camp, Chibougamau. In Geology and Metallogeny of the Chapais-Chibougamau Mining District: A New Vision of the Discovery Potential: Proceedings of the Chapais-Chibougamau 1998 Symposium; Pilote, P., Ed.; Quebec Ministry of Communications: Quebec City, QC, Canada, 1998; pp. 85-92.

34. Aminzadeh, B.; Shahabpour, J.; Maghami, M. Variation of Rhenium Contents in Molybdenites from the Sar Cheshmeh Porphyry Cu-Mo Deposit in Iran. Res. Geol. 2011, 61, 290-295.

35. Xiong, Y.; Wood, S. Experimental determination of the hydrothermal solubility of $\mathrm{ReS}_{2}$ and the $\mathrm{Re}-\mathrm{ReO}_{2}$ buffer assemblage and transport of rhenium under supercritical conditions. Geochem. Trans. 2002, 3, 1-10. 
36. Voudouris, P.C.; Melfos, V.; Spry, P.G.; Bindi, L.; Kartal, T.; Arikas, K.; Moritz, R.; Ortelli, M. Rhenium-rich molybdenite and rheniite in the Pagoni Rachi Mo-Cu-Te-Ag-Au prospect, Northern Greece: Implications for the Re Geochemistry of porphyry style $\mathrm{Cu}-\mathrm{Mo}$ and Mo mineralization. Can. Mineral. 2009, 47, 1013-1036.

37. Selby, D.; Creaser, R. Re-Os Geochronology and systematic in molybdenite from the Endako porphyry molybdenum deposit, British Columbia, Canada. Econ. Geol. 2001, 96, 197-204.

38. Ciobanu, C.L.; Cook, N.J.; Kelson, C.R.; Guerin, R.; Kalleske, N.; Danyushevsky, L. Trace element heterogeneity in molybdenite fingerprints stages of mineralization. Chem. Geol. 2013, 347, 175-189.

39. Naumov, A. Rhythms of Rhenium. Russ. J. Non-Ferr. Met. 2007, 48, 418-423.

40. Jiang, K.; Wang, Y.; Zou, X.; Zhang, L.; Liu, S. Extraction of molybdenum from molybdenite concentrates with hydrometallurgical processing. JOM 2012, 64, 1285-1289.

41. Lan, X.; Liang, S.; Song, Y. Recovery of rhenium from molybdenite calcine by a resine-in-pulp process. Hydrometallurgy 2006, 82, 133-136.

42. Fatai, I. Purification of Molybdenite Concentrates. Master's Thesis, Luleå University of Technology, Luleå, Sweden, 2008; p. 89.

43. Bulatovic, S.M. Handbook of Flotation Reagents-Chemistry, Theory and Practice: Flotation of Sulfide Ores; Elsevier: Amsterdam, The Netherlands, 2007.

44. Triffett, B.; Veloo, C.; Adair, B.; Badshaw, D. An investigation of the factors affecting the recovery of molybdenite in the Kennecott Utah Copper blulk flotation circuit. Miner. Eng. 2008, 21, 832-840.

45. Zanin, M.; Ametov, I.; Grano, S.; Zhou, L.; Skinner, W. A study of mechanisms affecting molybdenite recovery in a bulk copper/molybdenum flotation circuit. Int. J. Miner. Process. 2009, 93, 256-266.

(C) 2014 by the authors; licensee MDPI, Basel, Switzerland. This article is an open access article distributed under the terms and conditions of the Creative Commons Attribution license (http://creativecommons.org/licenses/by/4.0/). 